\title{
Magnetic susceptibility, magnetic mineralogy and magnetic fabrics in a late Archean granitoid-gneiss belt
}

\author{
K. Benn ${ }^{\mathrm{a}}$, P. Rochette ${ }^{\mathrm{b}, *}$, J.L. Bouchez ${ }^{\mathrm{c}}$ and K. Hattori ${ }^{\mathrm{a}}$ \\ attawa-Carleton Geoscience Center, Department of Geology, University of Ottawa, 161 Louis Pasteur, Ottawa, Ont., K1N 6N5, \\ Canada

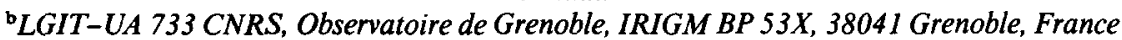 \\ ${ }^{\mathrm{c}}$ Laboratoire de Pétrophysique et Tectonique, Université Paul-Sabatier, 38 rue des 36 Ponts, 31400, Toulouse, France
}

Received July 10, 1992; revised version accepted November 25, 1992

\begin{abstract}
The Opatica belt is a late Archean granitoid-gneiss terrane situated within the northern Abitibi Subprovince, along the northern margin of the Abitibi greenstone belt, Quebec. This belt is composed of several suites of tonalite-granodioritegranite composition, variably deformed under epidote-amphibolite to upper-amphibolite grade conditions. Specimens from 87 sampling sites within the Opatica belt show a wide range in variation of magnetic susceptibility $(\bar{K})$; the large variations are due essentially to varying proportions of ferromagnetic trace minerals. Detailed study of the opaque mineralogy by reflected light petrography, electron microprobe analysis and SEM observations, as well as alternating field and thermal demagnetization experiments confirm that multi-domain, very pure magnetite is the dominant ferromagnetic phase which, along with ferrosilicates, contribute to the magnetic susceptibility. In some cases, hematite may also make a significant contribution to $\bar{K}$. In rocks with low $\bar{K}$, the susceptibility may be dominated by the ferrosilicates hornblende and biotite. Intensity of anisotropy of magnetic susceptibility (AMS) is also highly variable, and appears to be controlled by the mineralogy of the rock rather than by strain intensity or deformation state. The shapes of AMS ellipsoids are also controlled by mineralogy. Detailed comparisons are made of AMS fabrics with field measurements of magmatic and metamorphic foliations and mineral and stretching lineations, and with mineral lineations determined by image analysis of polished slabs. There is very good agreement between the average orientations of poles to structural foliations, and the average orientation of the $K_{3}$ principal axes of the susceptibility ellipsoids in all outcrops. In most cases, there is also good agreement between average structural lineations and the average $K_{1}$ axis. In quartz-monzodiorites, disagreement betweer the average lineation and average $K_{1}$ may be due to complex textural occurrences of magnetite, and the presence of abundant hematite. In gneisses, broad scatter of the orientations of $K_{1}$ for individual samples from an outcrop (quantified by statistical confidence regions about the principal axes) locally occurs within the foliation plane, and may be attributed to the partial overprinting of earlier fabrics by subsequent deformation.
\end{abstract}

\section{Introduction}

Granite-gneiss belts, along with plutons and intrusive complexes within granite-greenstone and metasedimentary belts, represent by far the largest surface area in most cratons of known Archean age. With this in mind, struc-

Correspondence to: K. Benn, Ottawa-Carleton Geoscience Center, Department of Geology, University of Ottawa, 161 Louis Pasteur, Ottawa, Ont., K1N 6N5, Canada. *Now at: Faculté St.-Jérôme, case 431, 13397 Marseille Cédex 13, France. tural studies of crystalline rocks should be considered of prime importance in developing tectonic models for Archean cratons. Plutons may be emplaced at various stages during regional deformation, and thus record much of the tectonic evolution of a terrane. In some cases, granite-gneiss belts may be representative of the middle to lower crust underlying adjacent supracrustals. For example, it has been proposed that the Kapuskasing-Wawa gneiss would represent the deeper crust of the Wawa greenstones in northern Ontario (Percival and 
Card, 1983). It has also been suggested that the Opatica belt, which is the subject of this paper, represents the metamorphic-plutonic hinterland to a late Archean orogenic terrane which includes the Abitibi greenstone belt (Benn et al., 1992; Sawyer and Benn, 1993). Structural, petrological and geochronological information gathered from these rocks will extend constraints on the evolution of Archean orogens to middle and lower crustal levels. As well, structural analysis of granitic rocks can provide information on kinematics and strain in major movement zones.

In 1989, a LITHOPROBE funded study of the late Archean Opatica granite-gneiss belt was initiated (Fig. 1), involving over $200 \mathrm{~km}$ of structural mapping along three N-S traverses (Fig. 2). The results of this work have provided a regional perspective on the structure and composition of the Opatica, and provided new constraints on the tectonic evolution of the Abitibi Subprovince of the Canadian Shield (Benn et al., 1992; Sawyer and Benn, 1993). Principal elements in the structural make-up of the Opatica belt include regionally consistent mineral and stretching

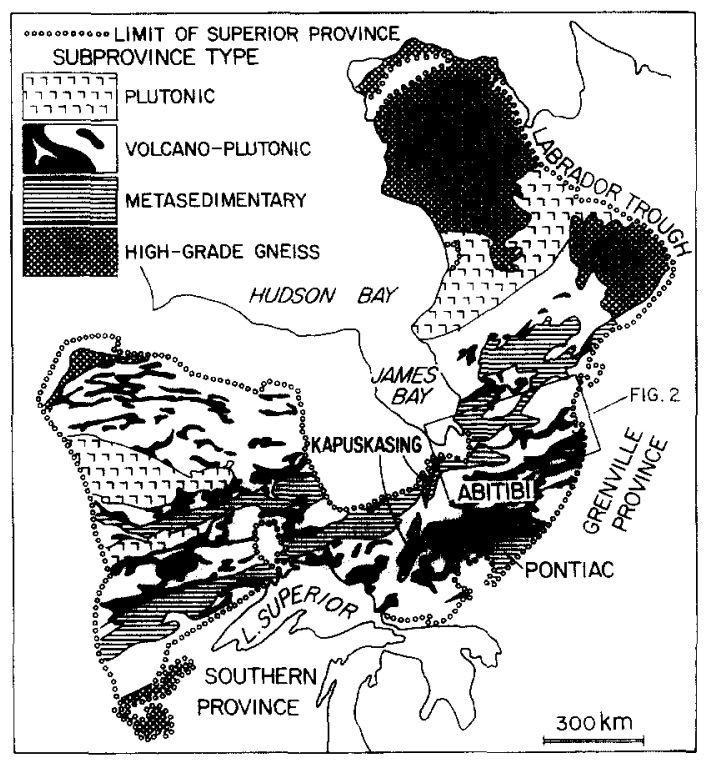

Fig. 1. Location map of the Opatica belt in Superior Province. The rectangle corresponds to Fig. 2.

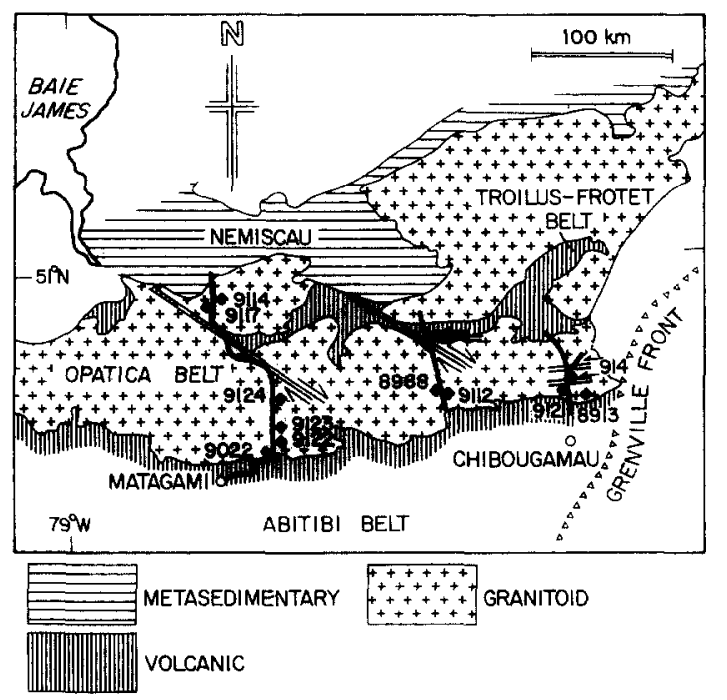

Fig. 2. Traverses mapped in the Opatica belt. Sampling sites corresponding to detailed fabric study are indicated. Major transcurrent ductile faults are also indicated.

lineations, associated with both deep-seated thrusting and major ductile transcurrent faults. Though crucial to regional kinematic analysis, lineations are often hard to determine accurately in the field, due to the flat, two-dimensional nature of outcrops. Lineations may be particularly difficult to determine in undeformed or weakly deformed granitoids, where the low-intensity mineral or stretching lineations may record the kinematics of crustal deformation during and following pluton emplacement. To help overcome this problem, we have tested the applicability of anisotropy of magnetic susceptibility (AMS) analysis (Hrouda, 1982; Borradaile, 1988) as a tool to indirectly measure mineral preferred orientation fabrics in a suite of rocks representative of various compositional types and deformational states. AMS has previously been successfully applied to the determination of petrofabrics orientations in a wide variety of rock types. In general, $K_{1}$, the maximum susceptibility direction, is used to approximate the mineral lineation, and $K_{3}$, the minimum susceptibility direction, is taken as the pole to the mineral foliation. 
The relationship between the petrofabric of a rock sample and the AMS fabric critically depends, however, on the mineral species present and textural relationships between minerals (Rochette, 1987; Jover et al., 1989; Borradaile et al., 1990; Rochette et al., 1992). Low-field AMS analysis renders a bulk magnetic fabric for the sample, which may be an average of two or more subfabrics corresponding to different minerals. Therefore, a detailed study of mineralogy is a requisite in basing any kinematic interpretation on AMS fabrics. For this reason, the magnetic mineralogy of different rock types was determined by detailed petrographic study, demagnetization experiments, electron microprobe analysis and scanning electron microscopy observations.

In this paper, we will present a highly detailed study of the magnetic mineralogy, magnetic susceptibilities and AMS of a suite of rocks from 87 sampling sites within the Opatica belt. Site average AMS fabrics will be compared to average foliations and lineations which were either measured in the field, or in the laboratory using a recently developed image analysis technique. It will be demonstrated that in most cases, the $K_{1}$ and $K_{3}$ principal axes of the AMS ellipsoid provide a good approximation of the mineral preferred orientations in an outcrop. Broad scatters of $K_{1}$ axes in some sampling sites will be related to complex oxide mineralogy, or to subtle composite fabrics arising from incomplete structural overprinting of deformation fabrics in gneissic rocks. The magnetic susceptibility and mineralogical data presented here may also provide a database for interpretation of aeromagnetic maps, and for eventual paleomagnetic studies in the area.

\section{Regional geology}

\section{Tectonic setting}

The southern part of the Archean Superior Province of the Canadian Shield is made up of an assemblage of ENE-WSW trending subprovinces (Goodwin, 1977), recently redefined on the basis of geological, structural, metamorphic and geophysical characteristics (Card and Ciesielski, 1986; Card, 1990; Fig. 1). Elongate volcano-plutonic and metasedimentary subprovinces in Minnesota, Manitoba and northwestern Ontario are truncated to the east by the NNE-SSW trending Kapuskasing structure, along which Archean lower continental crust has been upthrust (Percival and Card, 1983; Percival and McGrath, 1986). To the east lies the Abitibi volcano-plutonic subprovince, a significant component of which is the Abitibi belt, the largest continuous granite-greenstone belt in the world. Recent models of the late Archean tectonic evolution of southern Superior Province are based on analogies with Phanerozoic and modern-day plate margins. Petrologically, volcano-plutonic subprovinces are of dominantly calc-alkalic affinity, and are considered to represent remnants of magmatic arcs. Intervening metasedimentary subprovinces are interpreted as arc-related sedimentary basins or accretionary prisms.

Detailed structural studies limited to supracrustal assemblages in northwestern Ontario, suggest that accretion of magmatic arc terranes in the late Archean resulted in early thrusting and imbrication of crustal slices during bulk north-south compression (Poulsen et al., 1980; Hudleston et al., 1988; Williams, 1990), followed by large scale E-W transcurrent movements in a transpressional régime (Borradaile et al., 1988; Borradaile and Spark, 1991). LITHOPROBE seismic reflection profiles within the southern Abitibi Subprovince demonstrate the presence of well defined horizontal reflectors within the middle crust, which may be interpreted as thrusts (Jackson et al., 1990). Dimroth et al. (1983) proposed a tectonic model for the southern Abitibi Subprovince in Quebec, involving large-scale southward vergent thrusting of an island-arc terrane. 


\section{Geology of the Opatica}

Subprovince boundaries in Superior Province have been modified several times, and the name Opatica has been used to refer to different regions (see discussion in Benn et al., 1992). In this paper, we will use the term Opatica belt to refer to the granite-gneiss belt adjacent to the Abitibi greenstone belt on its northern side (Figs. 1 and 2), and which represents the northern parts of the Abitibi Subprovince as defined by Card and Ciesielski (1986). Though the Abitibi is one of the world's most studied Archean granite-greenstone belts, no work other than reconnaissance lithological mapping has been previously carried out in the Opatica belt just to the north. During 1989 and 1990, structural and lithological mapping was carried out along three $\mathrm{N}-$ $S$ traverses in the Opatica (Fig. 2). Detailed results of this work and a discussion of implications for the tectonic evolution of the Abitibi Subprovince are presented by Benn et al. (1992) and by Sawyer and Benn (1993). A brief summary of the geology and structure of the Opatica is presented here.

The crystalline rocks of the Opatica have been divided into four suites at the map scale. These suites and their relative ages are tentatively established by intrusive and structural relationships.

Suite 1 orthogneisses are composed of locally migmatitic grey tonalites and light grey to pink granodiorites. Highly sheared pegmatite is also locally present. These rocks are typically heterogeneous, and cross-cutting relationships between several intrusive phases are commonly preserved.

Suite 2 is made up of diorites, melanocratic to leucocratic tonalites and granodiorites. Granodiorites are locally porphyritic. These rocks often contain a compositional layering of magmatic origin which is better defined in the dioritic to melanocratic tonalites than in the more leucocratic rocks.

Suite 3 is dominated by quartz-monzodior- ites and granodiorites, also having well preserved magmatic layering. The relative age relationship of Suites 2 and 3 is uncertain, and these two suites may be genetically related.

Suite 4 is composed of biotite granites and pegmatites, most commonly pink but locally grey. Cross-cutting relationships prove that this is the latest plutonic suite in the Opatica. Dykes and sills of granite and pegmatite are locally more abundant than the older rocks, present only as xenoliths.

The only published isotopic date which might represent a magmatic crystallization age for Opatica rocks is a $2697 \pm 3 \mathrm{Ma} \mathrm{Pb}-\mathrm{Pb}$ isochron obtained by Gariépy and Allègre (1985). This date was determined on rocks belonging to our Suite 3, previously mapped as the Barlow pluton (Racicot et al., 1984), situated along the northern margin of the Abitibi greenstones. The four suites correspond to compositional types, and reflect, to a large degree, relative ages of emplacement.

Textural types have been defined according to microstructural criteria as (1) very weakly deformed, (2) LT (low temperature) epidote-amphibolite grade protomylonites to mylonites, and (3) HT (high temperature) amphibolite grade gneisses (Benn et al., 1992). Briefly, the textural characteristics of these types are as follows.

Type 1. Little microscale evidence of solid state deformation. Only quartz has undergone minor plastic strain. Highly dentate quartzquartz grain boundaries record high grain boundary mobility, indicating that deformation was under subsolidus conditions.

Type 2. Dynamic recrystallization, largely by rotation of subgrains, under upper-greenschist to epidote-amphibolite grade conditions. S-C fabric asymmetries (Berthé et al., 1979) are common, with chlorite-epidote-amphibole assemblages crystallizing along $\mathrm{C}$ surfaces.

Type 3. Complete or nearly complete $\mathrm{dy}$ namic recrystallizaton under amphibolite grade conditions involving high grain boundary mobility. These textures have been modified to 
varying degrees by static annealing. The preservation of coarse porphyroclasts suggest that these rocks are at least locally true HT mylonites (Hanmer, 1987).

Two principal deformation events have thus far been recognized in the Opatica. $D_{1}$ resulted in regional fabrics which are gently to moderately dipping foliations and mineral and stretching lineations, recording early thrusting. These fabrics are best developed within high strain zones with $\mathrm{L}>\mathrm{S}$ tectonite fabrics, and which are interpreted as ductile thrusts. Two families of mineral and stretching lineations are currently attributed to $D_{1}$. Lineations which are parallel to the belt (ENE-WSW) or transverse (NW-SE), tend to be dominant within structural domains. Further structural study, along with isotope geochronological results, should help determine if both families of lineations are in fact related to one tectonic event. $D_{1}$ structures have been reworked to widely varying degrees into open to tight, upright folds by later transpressive $D_{2}$ events which also resulted in the development of kilometer-scale transcurrent ductile faults (Fig. 2).

\section{Sampling}

From one to five cores, $25 \mathrm{~mm}$ in diameter, were collected from 87 sampling sites located along the three traverses. Sites are situated at least $300 \mathrm{~m}$ apart, and individual cores from each site were separated by 2 to $60 \mathrm{~m}$ in the field. One, two, or three samples, $22 \mathrm{~mm}$ in length, were cut from each core. All compositional and textural rock types are represented in the sampling population. Locations of samples selected for detailed comparison of AMS and structural fabrics are indicated in Fig. 2.

\section{Petrographic study of opaque mineralogy}

Twenty-one representative samples were chosen for a reflected-light petrographic study. A summary of observations is given in Table 1. Because optical identification of fine-grained oxides is difficult, more than 60 oxide grains from eight samples were examined using an electron microprobe and the quantitative chemical analysis of 40 grains was carried out using an energy dispersion spectrometer with operation conditions of $15 \mathrm{kV}, 10 \mathrm{nA}$ and 200 $s$ counting time. Furthermore, two samples, 8968 and 8977 , were selected for detailed examination of very fine-grained secondary magnetite using SEM.

In all rock types, varying amounts of magnetite occur as large ( $50 \mu \mathrm{m}-1200 \mu \mathrm{m})$, euhedral to subhedral grains, variably replaced by hematite both as lamellae along $\{111\}$, and along grain boundaries and fractures (Fig. 3a). In magmatic rocks and LT deformed equivalents, magnetite also typically occurs as anhedral inclusions (generally $<20 \mu \mathrm{m}$ ) in ferrosilicate minerals, and as tabular, very fine grains aligned within biotite and secondary chlorite cleavage planes. These secondary magnetites have grain sizes $<1 \mu \mathrm{m}$ (Fig. 3b). Advanced replacement of magnetite by hematite is typical of the Suite 3 rocks (especially quartzmonzodiorites), where magnetite grains may be almost entirely replaced (Fig. 3c). Abundant titanite is invariably associated with the hematite in Suite 3 , and oxide textures are complex. In Suites 2, 3 and 4, coarse-grained ilmenite $(50 \mu \mathrm{m}-1200 \mu \mathrm{m})$ is often present, always in subordinate amounts to magnetite. Hematite lamellae are common in ilmenite grains (Fig. 3d), and hematite and rutile are also present as fine-grained aggregates replacing ilmenite. In general, hematite is most abundant in Suite 3. In Suite 1 gneisses, magnetite occurs as coarse grains, sometimes with very thin rims of hematite and minor hematite replacement along cracks, and as small tabular grains aligned within biotite and hornblende cleavages. Pyrite has been observed in trace amounts in all rock types. 
TABLE 1

Opaque mineralogy

\begin{tabular}{|c|c|c|c|c|c|c|c|c|c|c|c|c|c|c|}
\hline \multirow[t]{2}{*}{ Sample } & \multirow{2}{*}{$\begin{array}{l}\text { Compositional } \\
\text { type }\end{array}$} & \multirow{2}{*}{$\begin{array}{l}\text { Textural } \\
\text { type }^{\mathrm{a}}\end{array}$} & \multicolumn{4}{|c|}{$\mathrm{mt}$} & \multirow[t]{2}{*}{ ilm } & \multirow[t]{2}{*}{ ilm-ht } & \multicolumn{4}{|l|}{ ht } & \multirow[t]{2}{*}{ rut } & \multirow[t]{2}{*}{ py } \\
\hline & & & A & $\mathbf{B}$ & $\mathrm{C}$ & $\mathrm{D}$ & & & A & B & $\mathrm{C}$ & $\mathrm{D}$ & & \\
\hline 8913 & hb-qz monzodiorite & 1 & $\mathbf{a}$ & $\mathrm{m}$ & $\mathbf{m}$ & & $\mathrm{t}$ & $\mathrm{m}$ & $\mathbf{a}$ & $\mathrm{a}$ & $\mathbf{m}$ & $\mathrm{t}$ & $\mathrm{t}$ & $\mathrm{t}$ \\
\hline 8916 & bt-hbl tonalite & 1 & $\mathbf{a}$ & & & & & a & $\mathrm{m}$ & $\mathrm{m}$ & & & & \\
\hline 8924 & bt tonalite & 1 & & & & & & & $\mathrm{~m}$ & $\mathbf{a}$ & & & & \\
\hline 8927 & bt tonalite & 1 & $\mathrm{~m}$ & & & & & & & & $\mathbf{m}$ & & $\mathrm{m}$ & $\mathrm{t}$ \\
\hline 8962 & px-bt-hbl tonalite & 1 & $\mathrm{a}$ & $\mathrm{m}$ & $\mathbf{m}$ & $\mathrm{m}$ & & $\mathrm{m}$ & $\mathrm{m}$ & $\mathrm{m}$ & & & & $t$ \\
\hline 8976 & bt tonalite & 1 & $\mathbf{a}$ & & & & & & & & & & & $\mathrm{t}$ \\
\hline 8977 & bt tonalite & 1 & a & & & $\mathrm{t}$ & & & & $\mathrm{m}$ & $\mathrm{m}$ & & & \\
\hline 918 & bt tonalite & 1 & $\mathrm{~m}$ & & $\mathrm{t}$ & & & & & $\mathrm{t}$ & & & & \\
\hline 8967 & bt granite & 1 & $\mathbf{a}$ & & & & $\mathbf{t}$ & $\mathbf{t}$ & & $\mathrm{m}$ & $\mathrm{t}$ & & $\mathrm{t}$ & \\
\hline 8968 & bt granite & 1 & $\mathbf{a}$ & & & & & $\mathbf{t}$ & & $\mathrm{m}$ & & & $\mathrm{t}$ & \\
\hline 8981 & bt granite & 1 & $\mathbf{a}$ & & & $\mathrm{t}$ & $\mathbf{t}$ & $t$ & & & & & $\mathrm{t}$ & \\
\hline 8929 & px-hb-qz monzodiorite & 2 & $\mathbf{a}$ & & & & & & & $\mathrm{m}$ & $\mathrm{m}$ & $\mathrm{t}$ & & \\
\hline 8957 & px-hb-qz monzodiorite & 2 & $\mathrm{~m}$ & & & & & $\mathrm{~m}$ & & $\mathrm{~m}$ & $\mathrm{a}$ & $\mathrm{t}$ & $\mathrm{t}$ & \\
\hline 912 & bt tonalite gneiss & 3 & $\mathrm{~m}$ & & $\mathrm{t}$ & & & & & $\mathrm{t}$ & & & & \\
\hline 9114 & bt hbl tonalite gneiss & 3 & $\mathrm{a}$ & & $\mathrm{m}$ & & & & & $\mathfrak{t}$ & & & & $\mathrm{t}$ \\
\hline 9121 & bt hbl tonalite gneiss & 3 & $t$ & & & & & & & & & & & \\
\hline 9122 & hbl tonalite gneiss & 3 & $\mathbf{t}$ & & & & & & & & & & & $\mathrm{t}$ \\
\hline 914 & bt granodiorite gneiss & 3 & $\mathbf{m}$ & & & & & & & $\mathrm{t}$ & & & & \\
\hline 9117 & bt granodiorite gneiss & 3 & $\mathrm{t}$ & & & & & & & & & & & \\
\hline 9124 & bt granodiorite gneiss & 3 & $\mathrm{t}$ & & $\mathrm{t}$ & & & & & & & & & \\
\hline
\end{tabular}

See text.

Abbreviations. $\mathrm{mt}=$ magnetite; ilm =ilmenite; ilm-ht =ilmenite-hematite intergrowths; ht $=$ hematite; rut $=$ rutile; $p y=p y r i t e ;$ $\mathrm{qz}=$ quart $; \mathbf{p x}=$ pyroxene; $\mathrm{bt}=$ biotite; $\mathrm{hb}=$ hornblende; $\mathrm{a}=$ abundant; $\mathrm{m}=$ minor amounts; $\mathrm{t}=$ traces.

Types of occurrences. Magnetite: $A=$ coarse subhedral to euhedral; $B=$ fine-grained anhedral inclusions in pyroxene and/or hornblende; $C=$ tabular grains as inclusions within cleavage planes of biotite/hornblende; $D=$ secondary fine-grained inclusions in chlorite. Hematite: $\mathrm{A}=$ lamellae in magnetite; $\mathrm{B}=$ as rims and along cracks in magnetite; $\mathrm{C}=$ coarse grains probably as replacement of coarse-grained magnetite; $D=$ fine grains in ferromagnesian silicates, or as aggregates.

All magnetite grains analyzed have compositions of nearly pure $\mathrm{Fe}_{3} \mathrm{O}_{4}$ independent of grain sizes and their occurrences. They are essentially free of $\mathrm{TiO}_{2}, \mathrm{Cr}_{2} \mathrm{O}_{3}, \mathrm{MnO}$, and $\mathrm{V}_{2} \mathrm{O}_{5}$ $(<0.3 \mathrm{wt} . \%)$. Even the central cores of coarse magnetite grains of size $>1 \mathrm{~mm}$ do not contain appreciable $\mathrm{Ti}$. The nearly pure magnetite compositions are attributed to sub-solidus reequilibration of the oxides.

Hematite is known to potentially contain significant amounts of $\mathrm{Ti}$, and the $\mathrm{Ti}$ content is believed to affect the intensity of optical anisotropy (Ramsdohr, 1980). No $\mathrm{TiO}_{2}(<0.3$ wt.\%) was detected in hematites which appear to display strong bireflection.

\section{Magnetic identification of ferromagnetic minerals}

Very fine-grained opaque minerals may be difficult to identify using a petrographic microscope, but their presence could have a strong influence on AMS fabrics. The nature of the opaque mineralogy was therefore further studied through alternating field (AF) and thermal demagnetization of anhysteretic remanent magnetization (ARM), which is carried by the soft (low-coercivity) fraction of the magnetic minerals, and isothermal remanent magnetization (IRM), which concerns both soft and hard fractions. These experiments were carried out on representative samples of Suites 2, 

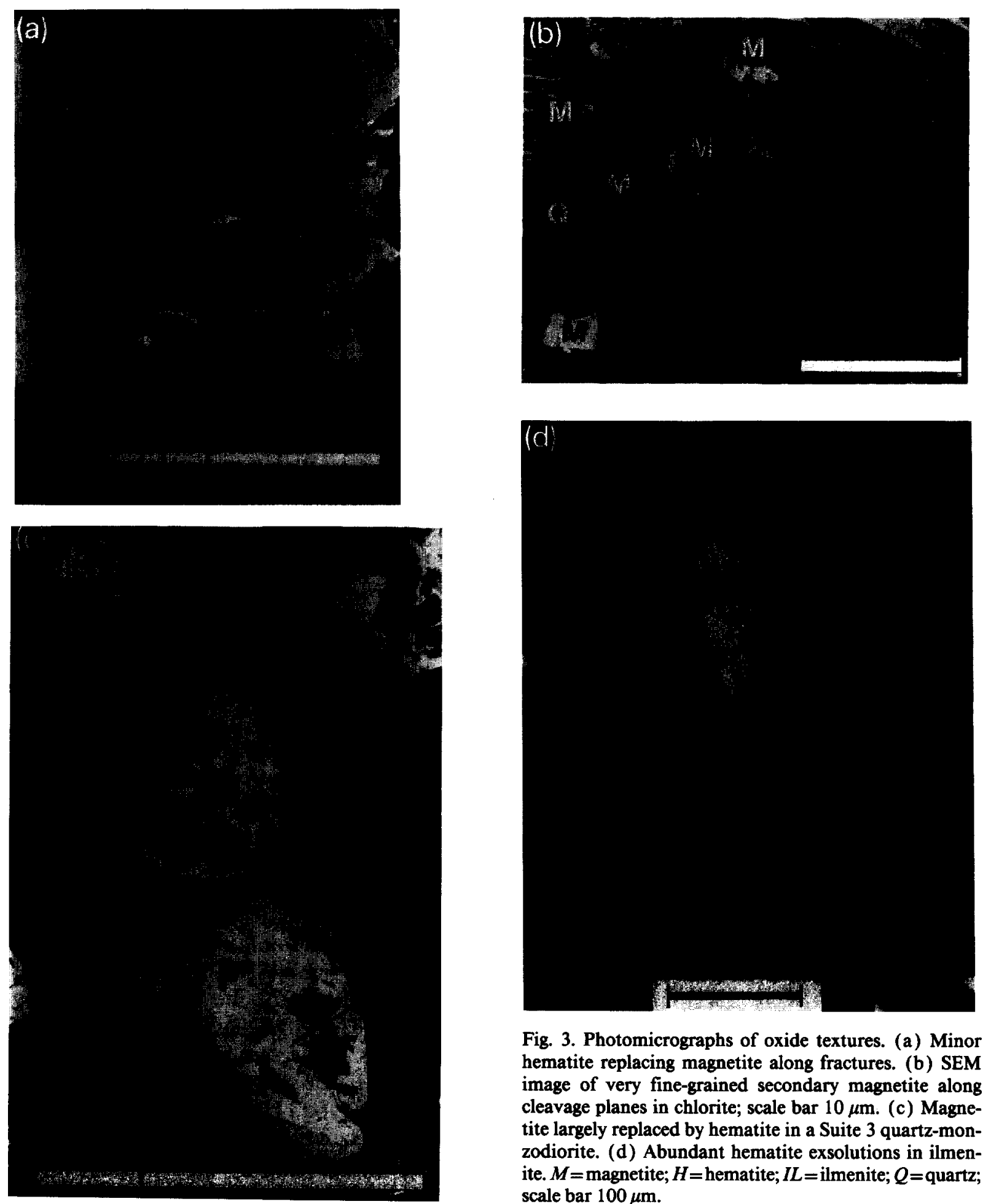

Fig. 3. Photomicrographs of oxide textures. (a) Minor hematite replacing magnetite along fractures. (b) SEM image of very fine-grained secondary magnetite along cleavage planes in chlorite; scale bar $10 \mu \mathrm{m}$. (c) Magnetite largely replaced by hematite in a Suite 3 quartz-monzodiorite. (d) Abundant hematite exsolutions in ilmenite. $M=$ magnetite; $H=$ hematite; $I L=$ ilmenite; $Q=$ quartz; scale bar $100 \mu \mathrm{m}$. 
3 and 4 , as the petrographic study has shown that their magnetic mineralogy may be complex (Table 1). Three successive sets of experiments were performed on each sample.

(1) Samples were cleaned of natural remanence in an AF of $100 \mathrm{mT}$. ARM was then imparted along the axis of the cylindrical samples in an AF of $100 \mathrm{mT}$, and a superposed coaxial direct field of $1 \mathrm{mT}$. Stepwise demagnetization was then carried out in AF's of 5, 10, 20, 30, $40,60,80$, and $100 \mathrm{mT}$.

(2) IRM was then induced in a direct field of $2.5 \mathrm{~T}$ along an axis perpendicular to the sample axis, and stepwise demagnetization was carried out in the same fashion as in the previous experiment.

(3) ARM was again induced perpendicular to the residual IRM in $100 \mathrm{mT}$ AF. Thermal demagnetization of this composite magnetization was carried out at temperatures of $150^{\circ}$, $200^{\circ}, 250^{\circ}, \ldots, 700^{\circ} \mathrm{C}$.

\section{AF demagnetization results}

Normalized results of experiments 1 and 2 are plotted in Figs. 4, 5 and 6. This type of diagram was proposed as a test to distinguish between AF demagnetization behavior of SD (single domain) and MD (multi domain) magnetic particles (Lowrie and Fuller, 1971), on the basis that resistance to AF cleaning of weak-field (ARM) acquisition would be greater than resistance to AF cleaning of highfield (IRM) acquisition for SD magnetite. For MD magnetite, resistance to AF cleaning would be greater for IRM. It was subsequently suggested (Johnson et al., 1975) that pseudo-single domain (PSD) magnetic particles would have similar AF demagnetization behavior to SD particles. Other workers have proposed that interpretation of this type of plot should be based on the shapes of the decay curves (Bailey and Dunlop, 1983). According to these authors, curves for SD and PSD magnetic particles would be inflected, with slow decay at both low and high AF's and more rapid decay at in- termediate AF's, while curves for MD particles would show rapid decay at low to moderate AF's and continuous but slower decay at high AF's. The net result of either of these two interpretations would be that for rocks with MD particles of one ferromagnetic phase, normalized IRM decay curves should plot above normalized ARM decay curves, while for SD and PSD particles, ARM should plot above IRM.

In a more detailed analysis of natural examples of various rock types (Dunlop, 1983) four types of weak field-high field AF decay curve combinations were defined, corresponding to (1) simple SD-PSD behavior, or (2) MD behavior, (3) the case where grain size is transitional from SD-PSD to MD behavior (between 4 and $15 \mathrm{~mm}$ ), and (4) bimodal behavior corresponding to two populations of ferro-magnetic grains, one with grain sizes $<4$ $\mathrm{mm}$ (SD or PSD) and the other with grain size $>15 \mathrm{~mm}$ (MD). Types 1 and 2 are limiting cases (see above paragraph). The goal behind the application of this test to our samples was to determine the presence or absence of significant amounts of SD or PSD ferromagnetic minerals, which may lead to incorrect estimations of petrofabrics from AMS fabrics (Rochette, 1988a; Potter and Stephenson, 1988).

Suite 2. AF decay curves for tonalites are plotted in Fig. 4. With the exception of sample 8977 , all the curves clearly correspond to MD type behavior, with IRM curves plotting above ARM curves, and only very slight inflections of curves for samples 8916,8961 and 8927 at $H<10 \mathrm{mT}$. For 8977 , the shapes of the decay curves indicate MD behavior, though the IRM curve plots below the ARM curve at $H>10$ $\mathrm{mT}$. The AF demagnetization plot for 8977 resembles the Type 3 (Dunlop, 1983), and would reflect the coexistence of magnetite in two distinct grain size populations (see also next section).

Suite 3. Plots for both samples of quartzmonzodiorite in Fig. 5 show MD type relative hardnesses, i.e. with IRM curves plotting above 

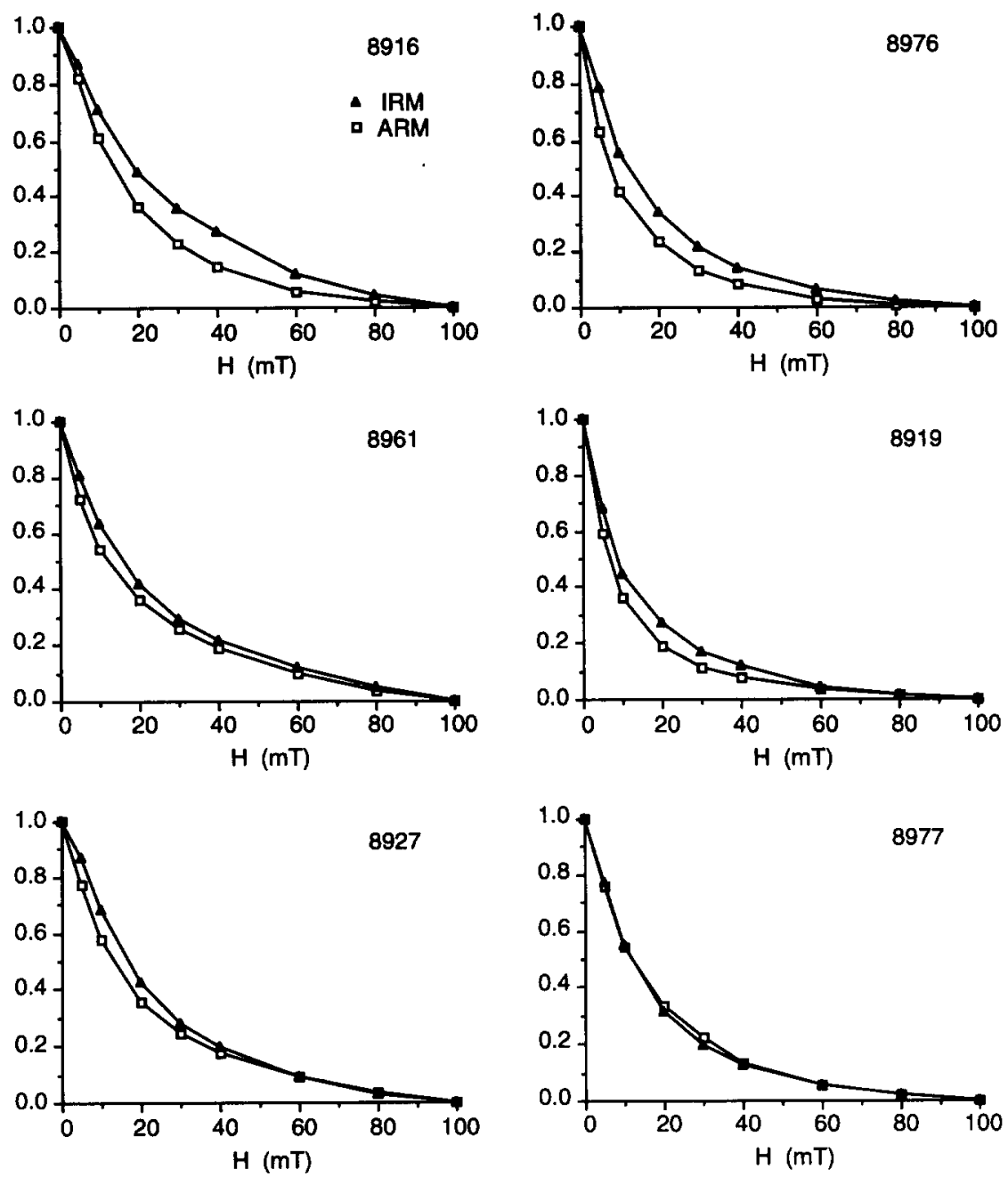

Fig. 4. Normalized AF demagnetization curves for IRM and ARM in Suite 2 rocks.
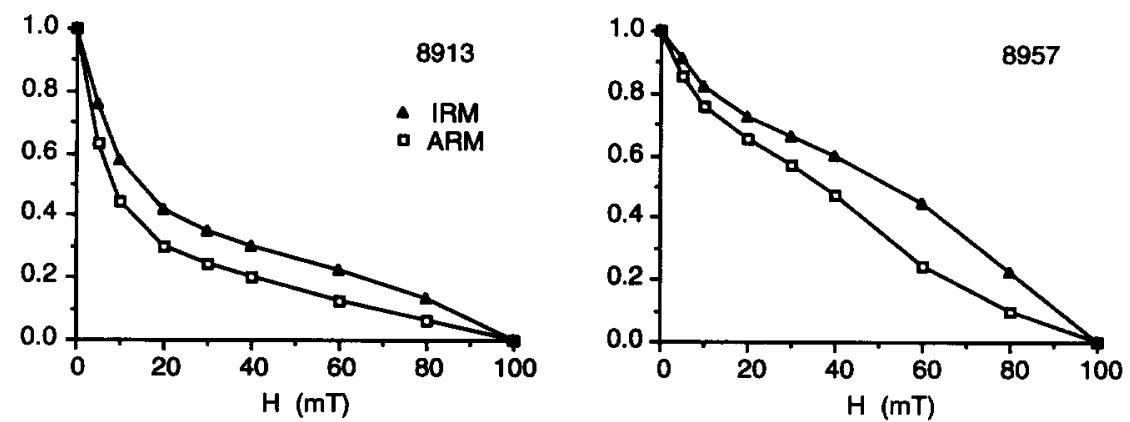

Fig. 5. Normalized AF demagnetization curves for IRM and ARM in Suite 3 rocks. 

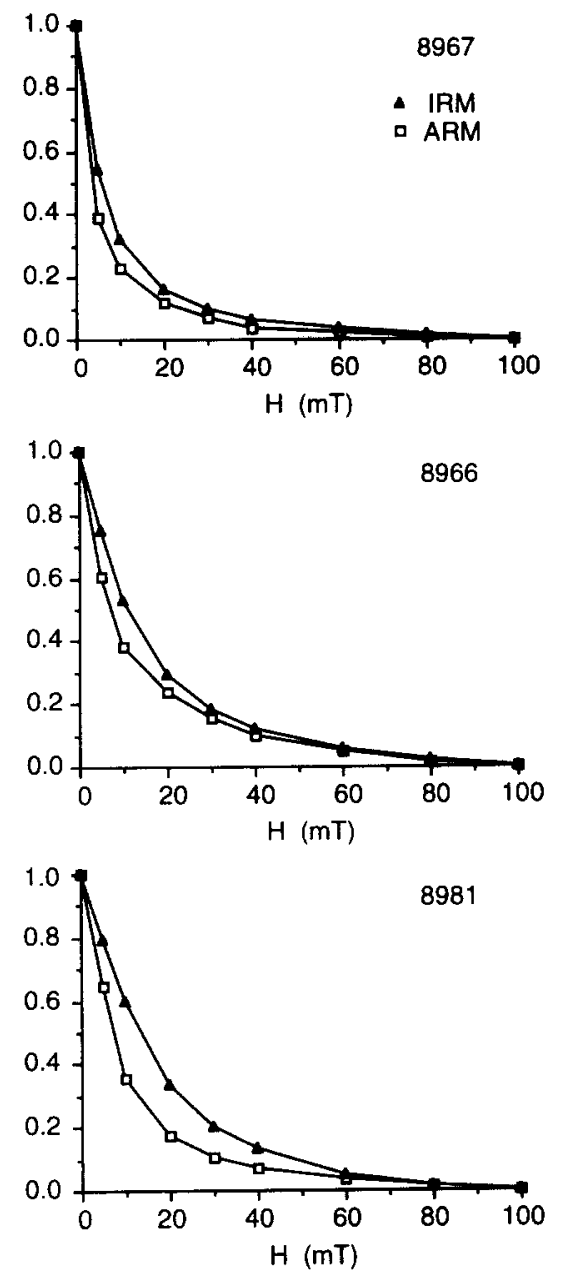

Fig. 6. Normalized AF demagnetization curves for IRM and ARM in Suite 4 rocks.

ARM curves. However, IRM decay rate decreases at intermediate AF's. This is most notable for sample 8957, where the decay rate for ARM also shows a slight decrease at 10 $\mathrm{mT}<H<30 \mathrm{mT}$. It is suggested that this type of behavior reflects the presence of a large proportion of hematite with respect to magnetite, as documented by reflected light petrography.

Suite 4. The AF demagnetization curves for pink granites presented in Fig. 6 all clearly show MD type behavior.

\section{Thermal demagnetization results}

Results of stepwise thermal demagnetization experiments of orthogonal components of IRM and ARM are plotted in Figs. 7, 8 and 9 for Suites 2, 3 and 4, respectively. Using this method, higher and weaker coercivity fractions of the ferromagnetic mineralogy are magnetized along mutually orthogonal directions, allowing separate analysis of the demagnetization behavior of the two fractions through decomposition of the total magnetic vector at each step in the experiment (Lowrie, 1990).

Suite 2 (Fig. 7). ARM initial $>\mathrm{IRM}_{\text {initial }}$ in tonalitic samples (with the exception of 8976) expressing a predominance of the low coercivity soft fraction of the opaque mineralogy. Characteristic unblocking temperatures for ARM of between $550^{\circ} \mathrm{C}$ and $600^{\circ} \mathrm{C}$ in samples $8916,8919,8927,8976$ and 8977 indicate the presence of magnetite. In 8916 and 8927 , ARM is only completely removed at $700^{\circ} \mathrm{C}$, indicating that $A R M$ is in part carried by hematite. In 8977, a second inflection in the ARM curve is evident at between $350^{\circ}$ and $400^{\circ} \mathrm{C}$. SEM observation of patches of chlorite replacing biotite in this sample reveals the presence of disseminated very fine-grained magnetite (Fig. 3b). We attribute the low unblocking temperature inflection to this very fine-grained secondary magnetite. Submicroscopic secondary magnetite (associated with chlorite) was invoked to explain unblocking temperatures of $300^{\circ} \mathrm{C}$ in the Archean Shelley Lake granite (Dunlop et al., 1984).

Various possible Curie points may be identified on the IRM curves: $650-700^{\circ} \mathrm{C}$ (hematite) for 8927 and $8916,550-600^{\circ} \mathrm{C}$ (nearly pure magnetite) for $8919,8927,8961$, and 8977 , and in the range $200-300^{\circ} \mathrm{C}$ for almost all the samples. The low Curie temperature may be due to very fine-grained magnetite, but is more probably due to a high coercivity mineral with its Curie point in this range. This mineral would probably be high-Ti hematite; 

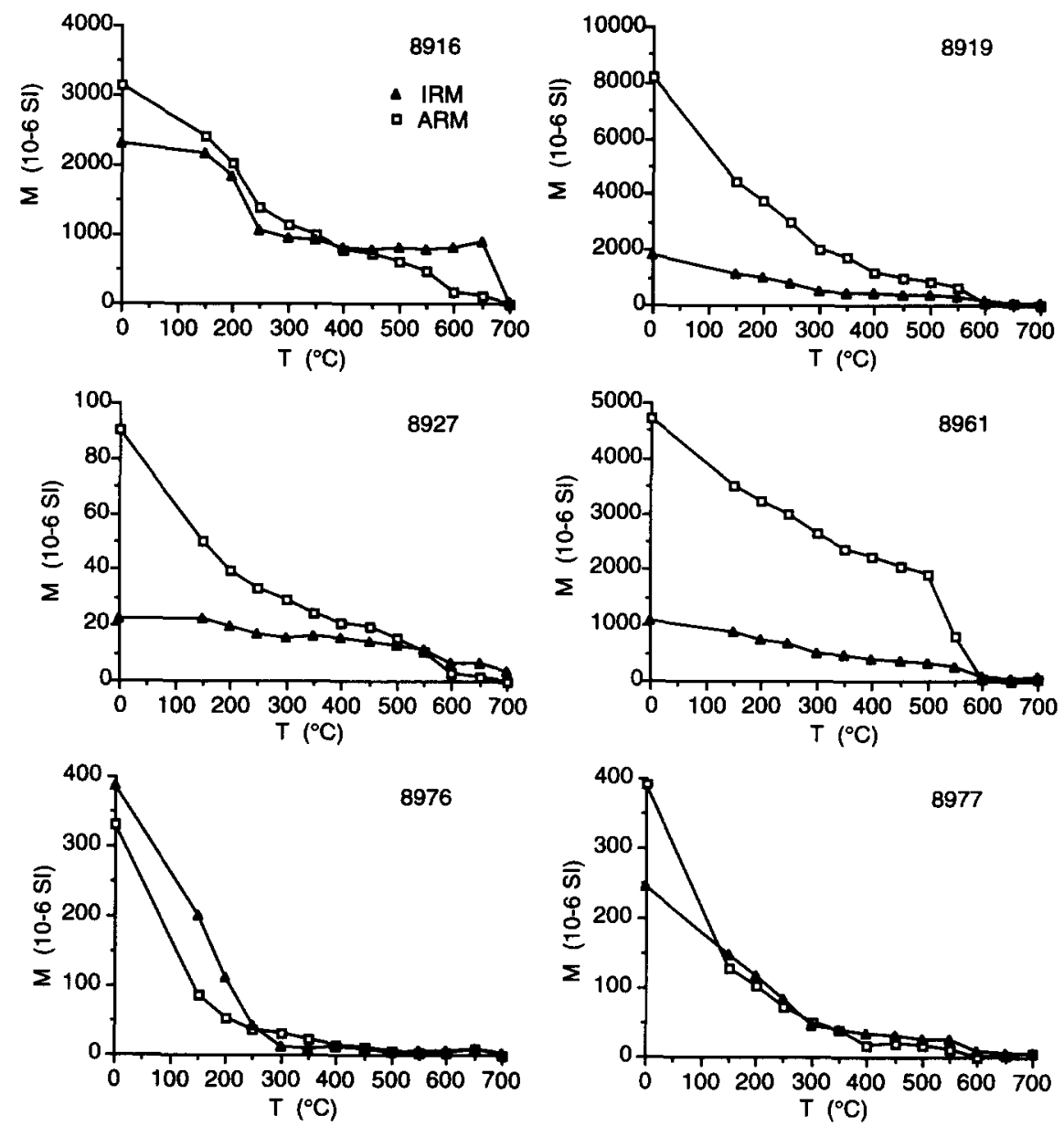

Fig. 7. Thermal demagnetization curves for IRM and ARM in Suite 2 rocks.
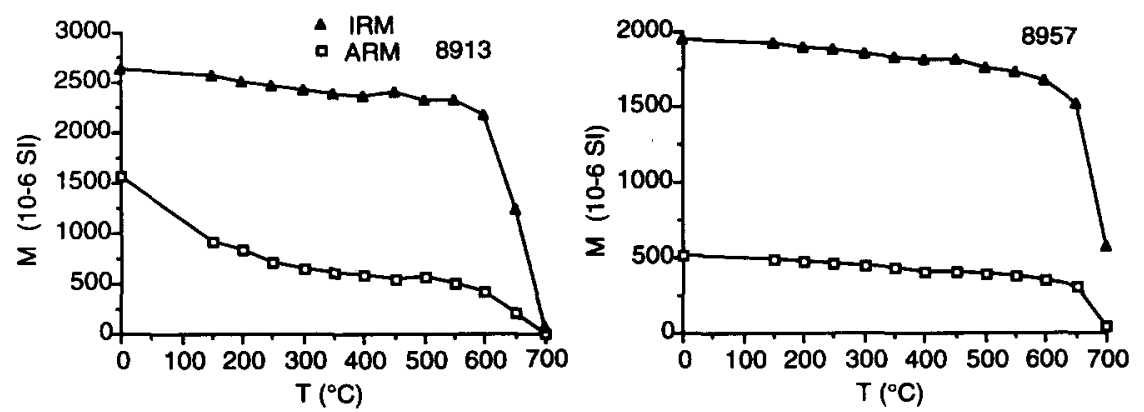

Fig. 8. Thermal demagnetization curves for IRM and ARM in Suite 3 rocks.

the other possibility, pyrrhotite, is excluded as it has never been observed in thin section.

Suite 3 (Fig. 8). IRM initial $_{\mathrm{ARM}_{\text {initial }} \text { and }}$ the characteristically high unblocking temperatures for both soft and hard fractions in quartz-monzodiorites reflect the presence of hematite as the predominant ferromagnetic phase, while the presence of magnetite is also detectable in the soft fraction of sample 8913.

Suite 4 (Fig. 9). In pink granites, hematite 

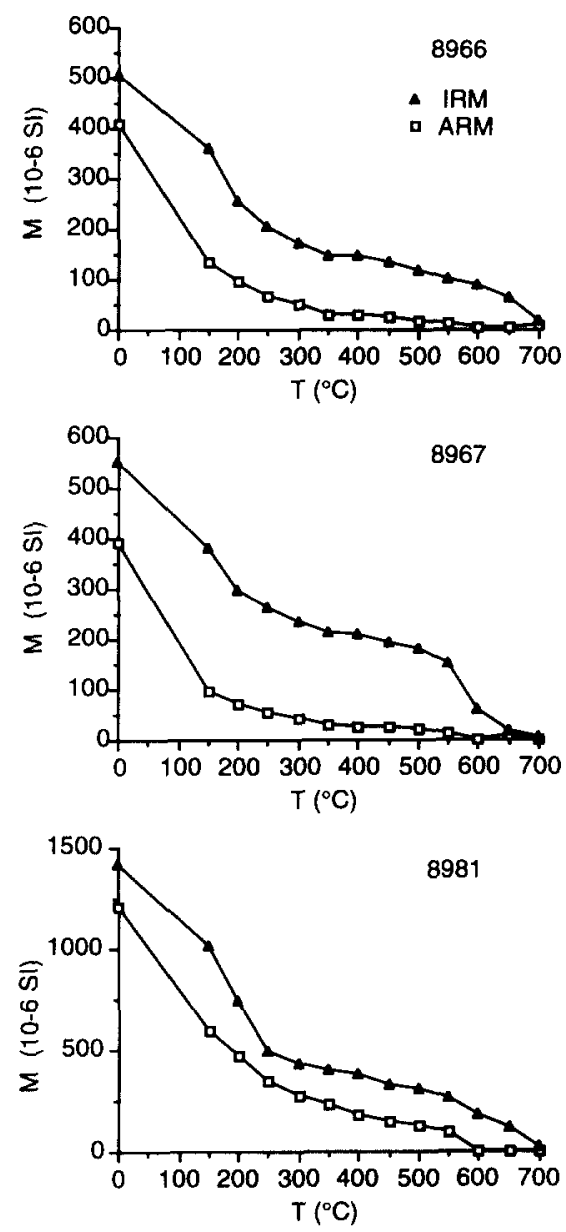

Fig. 9. Thermal demagnetization curves for IRM and ARM in Suite 4 rocks.

is clearly the dominant phase in the hard fraction, though some high-coercivity magnetite is detectable in 8967. The soft fraction in these rocks is clearly dominated by magnetite.

\section{Origin of the magnetic susceptibility}

Mean magnetic susceptibilities $\left(\bar{K}=\left(K_{1}+K_{2}+K_{3}\right) / 3\right.$; Ellwood et al., 1988), reported here in $10^{-6}$ SI units, were determined at room temperature, using a Kappabridge KLY-2 a.c. bridge, or for a few samples, a Molspin spinner magnetometer. Mean susceptibilities for all sample sites, along with maxima and minima are given in Table 2. Site average $\bar{K}$ is plotted in a cumulative frequency diagram in Fig. 10.

Site average $\bar{K}$ is extremely variable within the studied population $(58.5 \leqslant \bar{K} \leqslant 45654)$. This range of variation in $\bar{K}$ magnitudes is very similar to that reported for ten samples of various crystalline rock types from the Wawa gneiss dome in Ontario $(160 \leqslant \bar{K} \leqslant 32600$, Shive and Fountain, 1988). The higher susceptibility rocks compare well with silicic plutonic and gneissic rocks from the Pikwitonei and Sachigo Subprovinces in Superior Province (average $10^{-2}$ SI, Williams et al., 1986). From inspection of Table 2, the variations in $\vec{K}$ are independent of the compositional suites and textural types. This can be verified in Fig. 13 , which will be discussed in the next section. Suite 3 has a somewhat restricted variation in $\bar{K}$, but this may be due to a smaller sample population. Hornblende and biotite are the only paramagnetic minerals present in more than trace amounts in rocks at 84 of the 87 sample sites, though orthopyroxene and clinopyroxene are present at one site (8962) and clinopyroxene at two others $(8929,8963)$. In paramagnetic minerals, susceptibility, which varies with content of $\mathrm{Fe}$, and to a lesser extent Mn, cannot exceed about $10^{-3}$ SI. The estimated volume fractions of these ferromagnesian minerals is less than 0.25 , and rarely exceeds 0.30 . In Suite 4 , biotite accounts for volume fractions of about 0.05 . A first order observation of $\bar{K}$ values therefore indicates that the rock matrix composed of paramagnetic and diamagnetic minerals cannot alone account for susceptibilities at most of the sample sites, and that some ferromagnetic phase must be present.

A semi-quantitative approach to estimating the relative contributions of matrix and ferromagnetic trace minerals is obtained by plotting both $\bar{K}$ and $K_{\text {matrix }}$ against atomic weight percent of $\mathrm{Fe}$ and Mn (Fig. 11). $K_{\text {matrix }}$ is the maximum susceptibility of the rock supposing that all $\mathrm{Fe}$ and $\mathrm{Mn}$ is contained in the paramagnetic matrix (Rochette, 1987; Bouchez et al., 1987). Chemical analyses were obtained for 


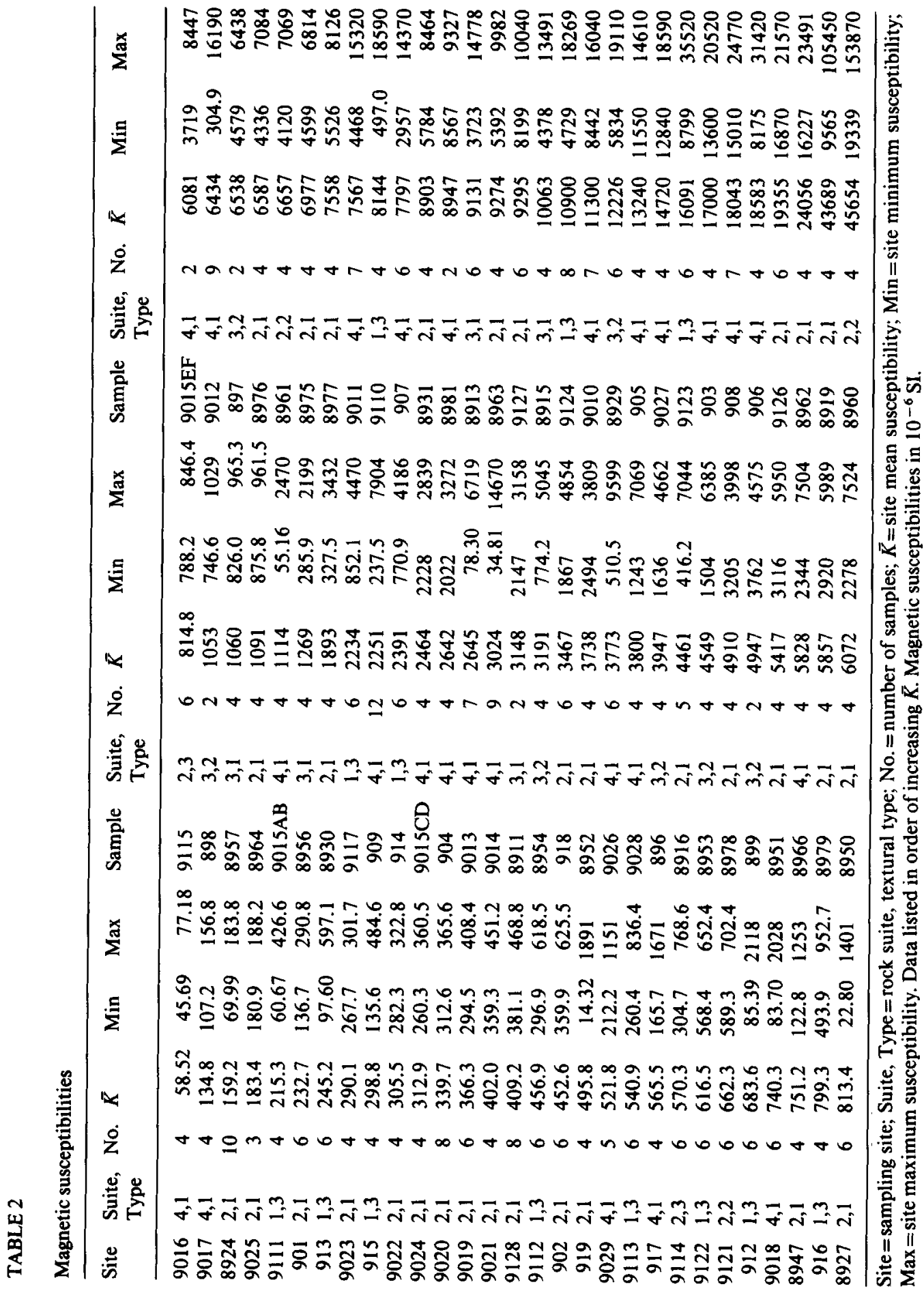




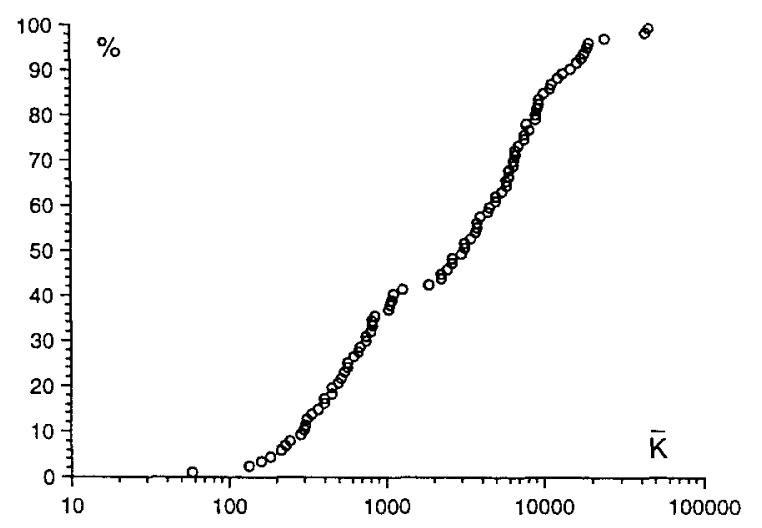

Fig. 10. Cumulative frequency diagram of site average magnetic susceptibilities.

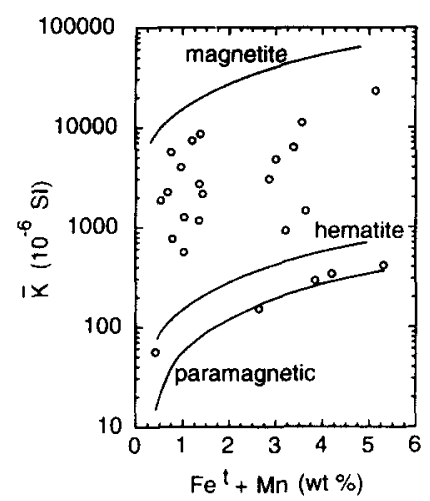

Fig. 11. Mean susceptibility ( $\bar{K}$; circles) as a function of whole rock iron ( $\mathrm{Fe}^{\mathrm{t}}$, all iron considered as $\mathrm{Fe}^{2+}$ ) and manganese $(\mathrm{Mn})$ content for 24 selected samples. The curve paramagnetic represents $K_{\text {matrix }}$ where all iron and manganese would be paramagnetic, and is calculated as $K_{\text {matrix }}=-14+\mathrm{d}\left(25.2 \mathrm{t}+33.4 \mathrm{t}^{\prime}\right) \quad$ (Rochette, 1987 ; Bouchez et al., 1987), where $t=w \mathrm{t} . \% \mathrm{Fe}, t^{\prime}=\mathrm{wt} . \% \mathrm{Mn}$, and $d$ (density) $=2.65$. Curves for all iron in hematite and magnetite are also shown.

24 samples with widely varying susceptibilities. It can be seen from Fig. 11 that for 16 of the 24 samples, a paramagnetic matrix containing all $\mathrm{Fe}$ and $\mathrm{Mn}$ in the rock could account for less than $10 \%$ of measured $\bar{K}$; in these samples, only the presence of a significant amount of magnetite could account for the high $\bar{K}$ values.

\section{Anisotropy of magnetic susceptibility}

To illustrate the AMS and to help determine the factors controlling the magnitudes and shapes of the AMS ellipsoids, we have chosen two widely used parameters:

$P=K_{1} / K_{3}$

the degree of anisotropy (Nagata, 1961), and:

$T=2\left(\ln K_{2}-\ln K_{3}\right) /\left(\ln K_{1}-\ln K_{3}\right)-1$

which characterizes the shape of the susceptibility ellipsoid (Hrouda, 1982; Borradaile, 1988 ) $. T=1$ for purely oblate ellipsoids, while $T=-1$ for purely prolate ellipsoids. In Fig. 12, $P$ is plotted against $\bar{K}$ for all sampling sites. Fields have been outlined for values of $P$ and $\bar{K}$ corresponding to rocks where susceptibility would be due exclusively to $10 \%$ biotite, $25 \%$ hornblende, or any amount of either of these two minerals plus magnetite ( \pm hematite). Susceptibility and anisotropy data for biotite and hornblende are found in Borradaile et al. (1987), Borradaile (1988) and Rochette et al. (1992). Two important observations can be made. First, at the vast majority of sites, magnetite makes a significant contribution to the susceptibility of the rocks, in agreement with Fig. 11. Second, rocks with $P>1.15$ are confined almost exclusively to the magnetite field. High anisotropy in these rocks can thus be correlated with the presence of ferromagnetics,

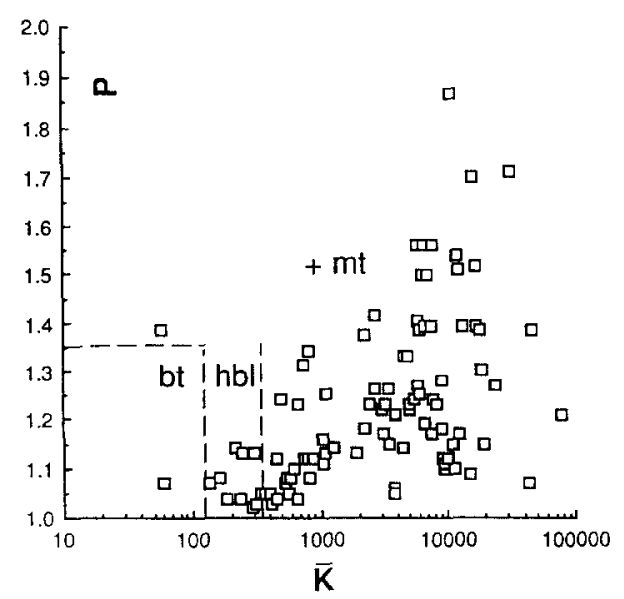

Fig. 12. Degree of anisotropy $P$ as a function of mean susceptibility $\bar{K}$ for all sampling sites. 

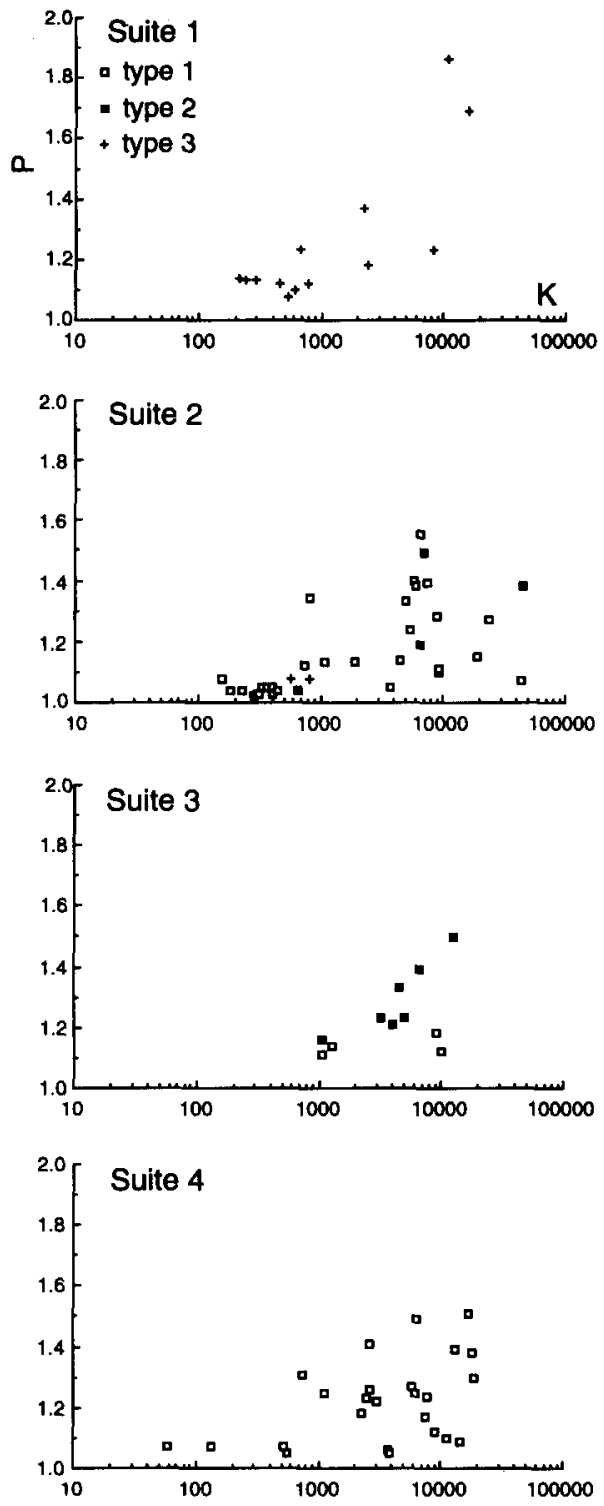

Fig. 13. The degree of anisotropy $P$ as a function of mean susceptibility $\vec{K}$ for different rock suites and textural types.

mostly anisometric magnetite grains.

In Fig. 13 , the $P$ vs. $\bar{K}$ plot is broken down according to the defined rock suites and textural types. Neither rock suites nor textural types can be clearly differentiated with regards to either their susceptibility or their anisotropy. Suites 2, 3 and 4 all have maximum anisotropies of about 1.6 , while only two samples of Suite 1 (all textural type 3 ) have $P$ greater
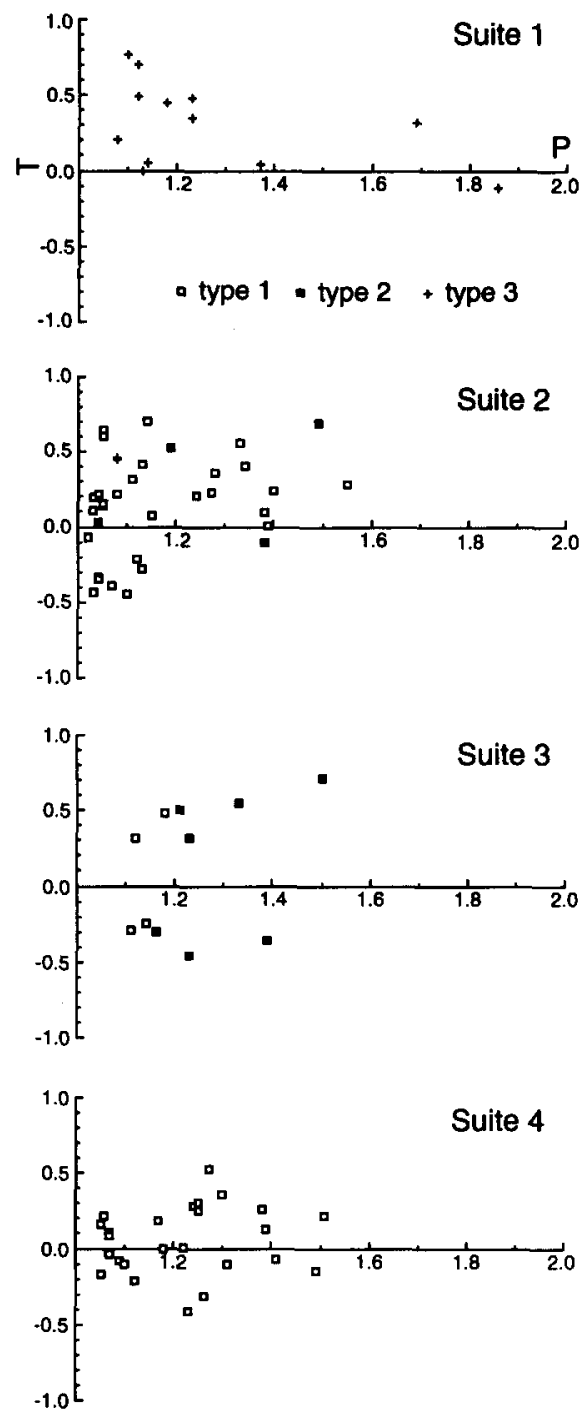

Fig. 14. The shape parameter $T$ as a function of the degree of anisotropy $P$ for different rock suites and textural types.

than this value. As a whole, the anisotropies for weakly deformed plutonic rocks are very similar to those for strongly deformed and recrystallized rocks. In the $T$ vs. $P$ plots of Fig. 14 , all but two sites in Suite 1 gneisses plot in the field of oblate AMS ellipsoids $(T>0)$. Interestingly, these gneisses can be classed as $\mathrm{L}>\mathrm{S}$ tectonites based on the field criteria of a very well developed stretching lineation but a poorly developed planar fabric; the shape of the AMS ellipsoid does not reflect the apparent 
deformation state of these rocks. In Suite 2, higher susceptibility sites tend to have oblate ellipsoids, whereas lower susceptibility sites for this suite, and all sites for Suites 3 and 4 have either oblate or prolate ellipsoids.

Our data indicate that both susceptibility and AMS intensity are strongly controlled by mineralogy. In general, $P>1.15$ is correlated with the presence of ferromagnetic trace minerals (mostly magnetite). With regards to HT textural types, a negative correlation might exist between the shapes of AMS ellipsoids $(T>0)$ and the apparent deformational state of the rock.

\section{Comparison of magnetic and structural fabrics}

\section{Data presentation}

A major objective of this work is to investigate the empirical relationships between magnetic and structural fabrics: i.e. does the orientation of the AMS ellipsoid closely reflect the magmatic and metamorphic mineral preferred orientations? In Figs. 15 and 16, we present direct comparisons of AMS and structural measurements plotted in lower hemisphere equalarea projections. In Fig. 15 , the $K_{1}$ and $K_{3}$ principal axes for 8 samples of textural type 3 (HT tonalite and granodiorite gneisses) are presented in the geographic coordinate system along with field measurements of lineations and foliations. In Fig. 16, $K_{1}$ and $K_{3}$ of three examples of very weakly deformed rocks (textural type 1) are plotted in a structural coordinate system; i.e., with the mineral lineation horizontal and the foliation in the plane of the diagram. In these weakly deformed rocks, mineral foliations were determined visually on oriented samples in the laboratory, and were found to be very nearly perpendicular to $K_{3}$ (Fig. 16). Mineral lineations were measured by applying a recently developed automated image analysis technique (Launeau et al., 1990), involving the analysis of shapes and orientations of object populations in digitized
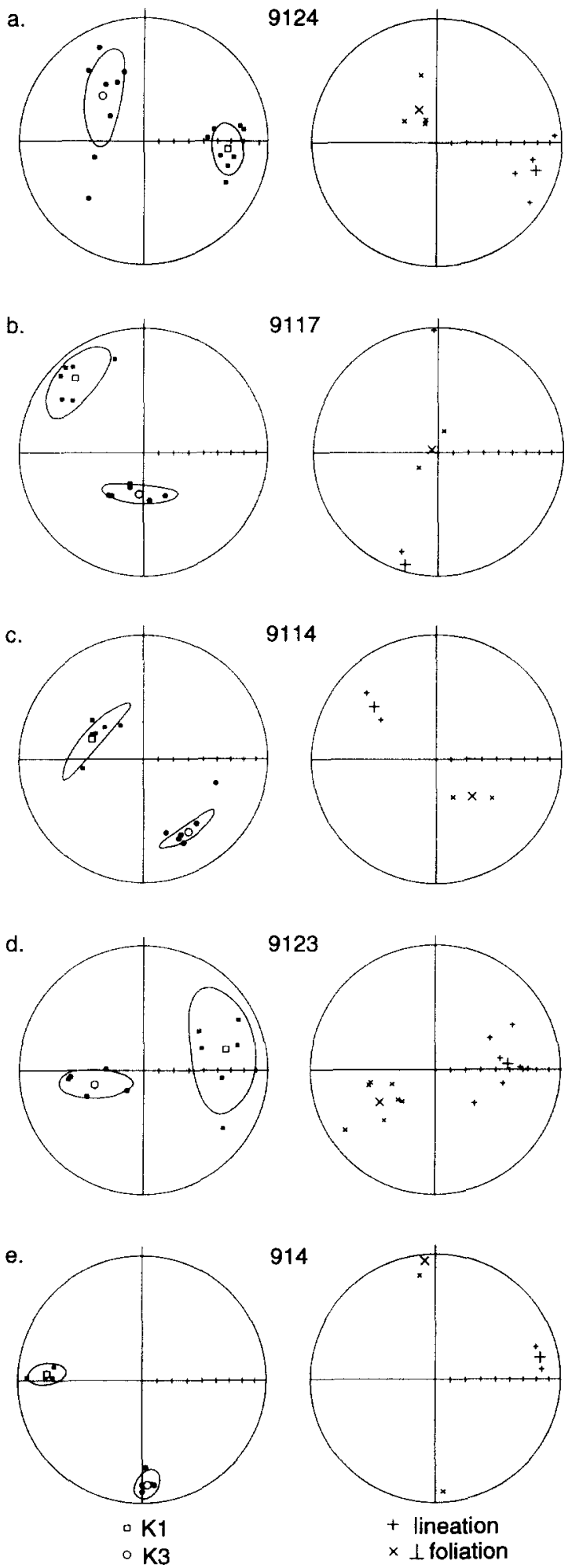
f.

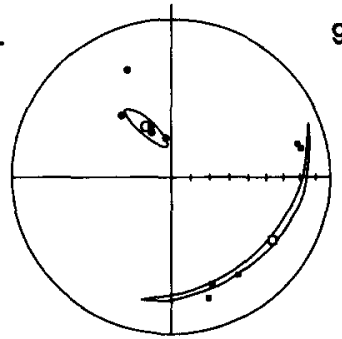

9112

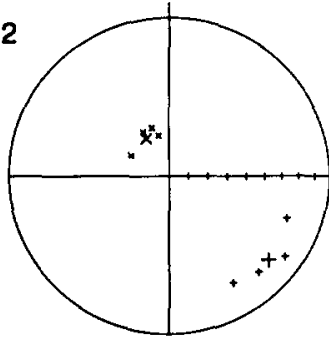

g.

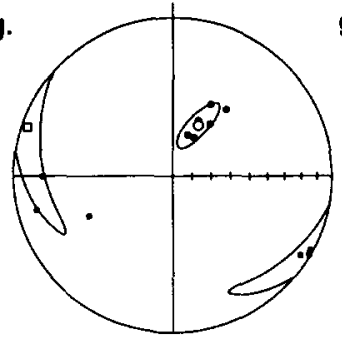

912

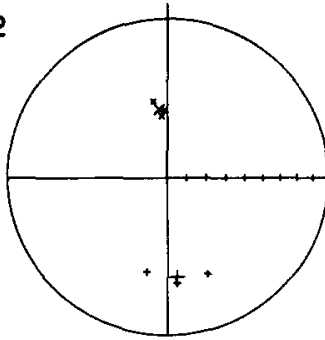

h.
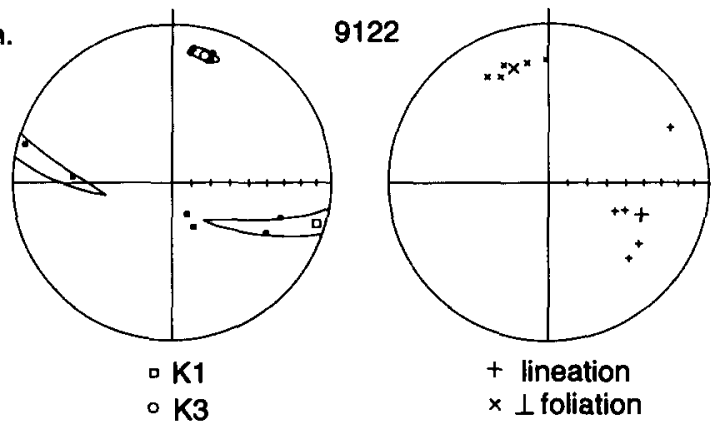

Fig. 15. Comparative equal-area plots of the $K_{1}$ and $K_{3}$ principal susceptibility axes and corresponding field measurements of lineations and poles to foliations in geographic coordinates. Average orientations are indicated by larger symbols. Elliptical regions in AMS fabric plots correspond to $95 \%$ confidence regions for the average. See also Table 3.

images of finite surface areas. In this application, the populations of dark minerals (biotite and subsidiary oxides) were analysed within rectangular areas traced on slabs cut parallel to the mineral foliation. Sample 8968 is a finegrained granite, for which two rectangular areas were analyzed. Angular differences between magnetic and structural fabrics are given in Table 3.

Average orientations of structural elements were calculated using a standard vector aver-
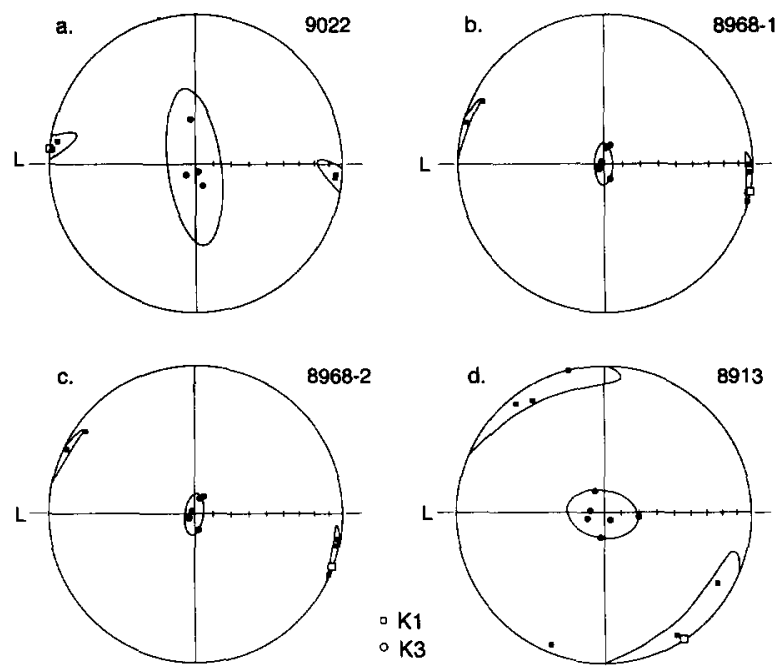

Fig. 16. Comparative equal-area plots of the $K_{1}$ and $K_{3}$ principal susceptibility axes and corresponding measurements of poles to foliations (vertical) and lineations (L). See also Table 3.

aging method. For AMS fabrics, the orientation of the mean normalized susceptibility tensor is plotted for each site, along with $95 \%$ confidence ellipses about each of the principal directions. Calculations and plots of mean tensors and confidence ellipses were carried out using software purchased from Geofyzika n. p. Brno. Use of the mean tensor for representing average AMS fabrics was suggested by Jelínek (1978), who outlined the method and pointed out its advantages over the averaging of the principal directions independently. (1) The principal directions of the mean normalized tensor are orthogonal. (2) Confidence ellipses about the principal directions may be calculated, which "express the directional character of uncertainty". (3) The normalization by $\bar{K}$ of the susceptibility tensor for individual specimens minimizes the error which may be introduced by very low-anisotropy, high-susceptibility specimens, whose principal directions may be less well defined. This is of particular importance in this study, where the susceptibility magnitudes may be highly variable at sampling sites (Table 2), due to variable contents of disseminated magnetite in individual 
TABLE 3

Comparison of magnetic and structural fabrics, average susceptibilities and error estimates

\begin{tabular}{|c|c|c|c|c|c|c|c|c|c|c|c|c|c|c|c|}
\hline \multirow[t]{2}{*}{ Sample } & \multirow[t]{2}{*}{ No. } & \multicolumn{2}{|l|}{$K_{1}$} & \multicolumn{2}{|l|}{$K_{3}$} & \multirow[t]{2}{*}{$K_{1} \wedge L$} & \multirow{2}{*}{$K_{3} \wedge \perp S$} & \multicolumn{2}{|l|}{$K_{1}$} & \multicolumn{2}{|l|}{$K_{2}$} & \multicolumn{2}{|l|}{$K_{3}$} & \multirow{2}{*}{$\begin{array}{l}\sigma K_{1} / \\
\left(K_{1}-K_{2}\right)\end{array}$} & \multirow{2}{*}{$\begin{array}{l}\sigma K_{3} / \\
\left(K_{2}-K_{3}\right)\end{array}$} \\
\hline & & $E_{1}$ & $E_{2}$ & $E_{\mathrm{l}}$ & $E_{2}$ & & & av & $\sigma$ & av & $\sigma$ & av & $\sigma$ & & \\
\hline 9124 & 8 & 15.2 & 11.3 & 32.7 & 12.4 & 17 & 19 & 1.3350 & 0.0824 & 0.9424 & 0.0547 & 0.7227 & 0.0546 & 0.2099 & 0.2485 \\
\hline 9117 & 6 & 23.8 & 16.0 & 24.8 & 6.5 & 61 & 29 & 1.1517 & 0.0397 & 1.0027 & 0.0226 & 0.8456 & 0.0621 & 0.2664 & 0.3953 \\
\hline 9114 & 6 & 32.2 & 6.2 & 18.7 & 5.0 & 23 & 25 & 1.0351 & 0.0175 & 1.0101 & 0.0081 & 0.9548 & 0.0152 & 0.7000 & 0.2749 \\
\hline 9123 & 6 & 37.5 & 24.0 & 25.3 & 9.0 & 11 & 12 & 1.2303 & 0.0282 & 1.0365 & 0.0298 & 0.7332 & 0.0557 & 0.1455 & 0.1836 \\
\hline 914 & 5 & 14.9 & 5.9 & 12.1 & 6.3 & 42 & 23 & 1.0685 & 0.0176 & 1.0218 & 0.0048 & 0.9097 & 0.0214 & 0.3769 & 0.1909 \\
\hline 9112 & 6 & 71.2 & 2.2 & 13.9 & 3.8 & 9 & 6 & 1.0463 & 0.0142 & 1.0198 & 0.0154 & 0.9339 & 0.0274 & 0.5358 & 0.3190 \\
\hline 912 & 6 & 50.6 & 7.6 & 15.3 & 4.9 & 66 & 18 & 1.0863 & 0.0548 & 1.0277 & 0.0226 & 0.8860 & 0.0611 & 0.9352 & 0.4312 \\
\hline 9122 & 6 & 37.5 & 24.0 & 25.3 & 9.0 & 34 & 29 & 1.0337 & 0.0080 & 1.0222 & 0.0038 & 0.9441 & 0.0094 & 0.6957 & 0.1204 \\
\hline 9022 & 4 & 19.8 & 4.4 & 43.9 & 14.4 & 6 & - & 1.0166 & 0.0014 & 0.9957 & 0.0004 & 0.9877 & 0.0011 & 0.0670 & 0.1375 \\
\hline $8968-1$ & 6 & 16.8 & 2.5 & 11.3 & 5.0 & 11 & - & 1.1486 & 0.0231 & 1.0188 & 0.0159 & 0.8326 & 0.0301 & 0.1780 & 0.1617 \\
\hline $8968-2$ & & & & & & 21. & - & & & & & & & & \\
\hline 8913 & 6 & 41.3 & 13.0 & 19.8 & 12.9 & 57 & - & 1.0670 & 0.0149 & 1.0225 & 0.0174 & 0.9105 & 0.0236 & 0.3348 & 0.2107 \\
\hline
\end{tabular}

No. = number of samples; $K_{1}, K_{2}, K_{3}=$ maximum, intermediate and minimum principal susceptibilities; $E_{1}, E_{2}=$ angular value of maximum and minimum semi-axes of the $95 \%$ confidence ellipse; $K_{1} \wedge L, K_{3} \wedge \perp S=$ angles between principal susceptibility directions and average orientations of structural fabric elements ( $L=$ lineation; $\perp S=$ pole to foliation ); av $=$ average; $\sigma=$ standard deviation.

specimens. By normalizing the susceptibility tensors, we are in fact approximating the anisotropy per unit volume of magnetic mineralogy (Ernst and Pearce, 1989).

Jelínek (1978) pointed out that the determination of confidence regions about the principal axes will be more precise as the variances of the principal susceptibilities of the mean tensor become smaller with respect to differences in susceptibilities along the principal directions, i.e., precision should be greater as the ratios:

$\sigma\left(K_{1}\right) /\left(K_{1}-K_{2}\right)$

and

$\sigma\left(K_{3}\right) /\left(K_{2}-K_{3}\right)$

become very small. He suggested that confidence ellipses could be considered valid if their semi-axes, expressed as confidence angles, did not exceed $25^{\circ}$. In a re-examination of the significance of the Jelinek confidence ellipses, Lienert (1991) found that they provided a good description of the AMS fabric distribution as long as the ratios (1) and (2) were $\leqslant 0.3$. For a ratio of about 1.0 , the confidence angles underestimated broad dispersions by about $10^{\circ}$. Lienert's work provides a yardstick with which our magnetic fabric data can be compared. To this end, Table 3 includes the normalized mean susceptibilities, standard deviations, ratios of standard deviations to susceptibility differences, the maximum and minimum confidence angles about $K_{1}$ and $K_{3}$, and the angles between the principal susceptibility directions and corresponding structural elements. This data will be discussed in the next section.

\section{Comparison of magnetic and structural fabric orientations}

The empirical relationship between AMS fabrics and structural fabrics has led to much interest in the possibility of inferring bulk rock petrofabrics from easily performed, non-destructive AMS analysis. Many previous investigations of the geometric relationship between planar and linear structural elements and the AMS ellipsoid in metamorphic rocks have 
shown that $K_{1}$ tends to be parallel to the mesoscopic mineral or stretching lineation, whereas $K_{3}$ tends to be perpendicular to the foliation (Khan, 1962; Wagner et al., 1981; Rathore, 1985; Pearce and Fueten, 1989). The same relationship has also been demonstrated for weakly deformed or undeformed granitoids (Guillet et al., 1983; Bouchez et al., 1990). From comparisons of magnetic and mesoscopic structural fabrics presented in the literature, the orientation of $K_{3}$ perpendicular to the foliation plane appears to be the general case, though some studies have shown that $K_{1}$ does not always approximate the mineral or stretching lineations. For instance, MacDonald and Ellwood (1990) found that the orientation of $K_{1}$ was close to intrafolial fold axes, and oblique to a prominent stretching lineation in mylonitic crystalline rocks within a detachment fault above a metamorphic core complex. Hrouda and Kahan (1991) also found a correlation of $K_{1}$ with intrafolial fold axes in deformed crystalline basement nappes of the High Tatra Mountains, Czechoslovakia. Ruf et al. (1988) studied AMS fabrics in mylonite zones in two detachment faults from metamorphic core complexes in the Santa $\mathrm{Ca}$ talina and Pinaleno Mountains. In the first example, they found $K_{1}$ to be coaxial with the structural lineation. However, for their second example it was shown that $K_{1}$ was not coincident with the stretching lineation, due to complicated oxide mineralogy including synkinematic crystallization of hematite.

By inspection of Figs. 15 and 16, it can be seen that the confidence regions agree well with the distributions of $K_{3}$ in all cases, though the dispersion of $K_{3}$ poles in Fig. 15a is somewhat underestimated. For all but two examples, the maximum confidence angles associated with $K_{3}$ are equal to or below the $25^{\circ}$ cut-off suggested by Jelínek. The ratio (2) for each sampling site is in general $<0.3$, and always $<0.5$. With regards to $K_{1}$, the confidence regions also show good agreement with the fabric distributions; however, for six of the eleven examples, confi- dence angles largely exceed $25^{\circ}$, and the ratio (1) is greater than 0.3 for five of these sites. By comparison with the results of Lienert (1991), the confidence regions may underestimate the error by a few degrees at these sites. In general, where the principal susceptibility is associated with a large confidence angle, the percentage of standard deviation with respect to principal susceptibility differences is relatively large (an exception is site 9123).

Let us now compare orientations of magnetic and structural fabrics, beginning with Figs. $15 a-15 e$ and $16 a-16 c$. In these examples, the confidence angles are small. Angular differences between the orientations of $K_{1}$ and $K_{3}$ and the corresponding structural elements are variable, exceeding $10^{\circ}$. Average $K_{3}$ is close to the average poles to mesoscopic foliations, and $K_{1}$ generally lies close to the averages of measured lineations. The large angles between $K_{1}$ and average lineation in Figs. $15 \mathrm{~b}$ and $15 \mathrm{e}$ are poorly defined, as only two field measurements are available for each. In Figs. $15 \mathrm{f}-15 \mathrm{~h}$ and $16 \mathrm{~d}$, confidence angles about $K_{1}$ are quite large; scatter of $K_{1}$ poles define broad partial to nearly complete girdles. In Figs. $15 \mathrm{f}-15 \mathrm{~h}$, ratio (1) is $>0.5$. Despite the wide scatter of $K_{1}$ and the weak linear anisotropy, $K_{1}$ is still very close to the average lineation in Fig. $15 f$. In Fig. 16d, there is a broad scatter in the orientations of $K_{1}$, the major confidence angle associated with this principal direction is large, and mean $K_{1}$ lies at $57^{\circ}$ from the measured lineation, despite a relatively strong linear magnetic fabric reflected by a low value for the ratio (1).

\section{Discussion}

For most of the examples presented here, the $K_{1}$ and $K_{3}$ principal directions of the AMS ellipsoid provide a good approximation of the orientations of the penetrative mineral foliations and lineations observed in the rocks. Carried out in conjunction with regional mapping, the AMS fabrics provide good estima- 
tions of the orientations of mineral and stretching lineations. It should be born in mind that the measurements of structural fabrics are themselves only approximations of the true mineral preferred orientations. As in many shield terranes, outcrops in the Opatica tend to be flat and two-dimensional, and the measurement of structural fabrics, in particular lineations, are not always highly accurate. With regards to Fig. 16, mineral preferred orientations were determined by image analysis of areas ranging from $76 \mathrm{~cm}^{2}$ to $103 \mathrm{~cm}^{2}$, on slabs cut from oriented samples.

In contrast, a sample analysed for AMS represents $10 \mathrm{~cm}^{3}$ of rock that can be collected with relative ease from evenly spaced locations on an outcrop. AMS fabric measurements might thus be considered as more representative of the petrofabric of ferromagnesian and ferromagnetic minerals than the field measurements or image analysis results. Good grouping of $K_{1}$ and $K_{3}$ in Figs. 15a-15e and 16a-16c also suggests that the magnetic fabrics represent well defined bulk petrofabrics.

Two explanations may be offered for the more poorly defined preferred orientations of average $K_{1}$ in Figs. $15 \mathrm{f}-15 \mathrm{~h}$ and Fig. 16d: mineralogy and interference of composite structural fabrics.

\section{Mineralogy}

The relationship between mineral preferred orientations and AMS critically depends on the minerals carrying the AMS signal. This work has shown that the principal species responsible for the susceptibility and the AMS of the Opatica rocks are magnetite, hornblende, and biotite, and to a lesser degree hematite. The magnetocrystalline AMS of most paramagnetic ferrosilicates, including hornblende and biotite, is such that principal directions are parallel to the shape anisotropies which are typical of the minerals. $K_{1}$ in hornblende is parallel to the $c$ crystallographic axis, which is also the elongate direction of the crystal habit.
$K_{3}$ in biotite is perpendicular to the basal plane, the alignment of which defines the structural foliation. The anisotropy $(P)$ for these minerals is $\leqslant 1.35$ (Rochette et al., 1992). For magnetite, the AMS is a function of the shape anisotropy; if the magnetite grains are elongate or flattened, $K_{1}$ will be parallel to the elongate direction and $K_{3}$ will be perpendicular to the broad flat faces. Hematite has a strong magnetocrystalline AMS, with $K_{3}$ perpendicular to the basal plane and $K_{1} \cong K_{2} \gg K_{3}$ (Uyeda, 1963 ) and $2.5 \leqslant P \leqslant 100$ (Rochette et al., 1992). Petrographic observations (Table 2) have shown that the quartz-monzodioritic rocks (for example 8913) tend to have complex oxide textures, with magnetite occurring as both discrete grains and inclusions in hornblende and biotite, and abundant hematite both as discrete grains and replacing magnetite. It is probable that the scatter of $K_{1}$ orientations in Fig. 16d, and more importantly the high angle between average $K_{1}$ and the measured lineation, which is a hornblende-biotite preferred orientation, is largely due to the complex oxide mineralogy. The preferred orientations of strongly anisotropic magnetite and hematite or inclusions of these minerals within silicates may not record the kinematics of deformation, which is here essentially magmatic flow. As this rock has undergone very little solid state deformation, these complex textures may be a primary petrological characteristic of this suite of rocks.

The wide scatter in $K_{1}$ poles in Figs. $15 \mathrm{f}-15 \mathrm{~h}$ must be explained otherwise. All three sites are within highly deformed and recrystallized rocks of Suite 1. Average susceptibilities at all three sites is low $\left(<700 \times 10^{-6} \mathrm{SI}\right)$, though a relatively large variation in $\bar{K}$ is was found for site 912 (Table 2). Petrographic observations confirm that these rocks contain only very small amounts of coarse magnetite, with, in some cases, very thin rims of hematite. We have found no correlation between the orientations of $K_{1}$ for individual samples at a site, and either $\bar{K}, P$ or $T$, as might be expected if distinct non- 
coaxial subfabrics could be attributed to different mineral species.

\section{Interference of structural fabrics}

Two families of early $\left(D_{1}\right)$ mineral and stretching lineations have been documented within HT tonalite and granodiorite gneisses throughout the Opatica (Benn et al., 1992), one family trending WSW-ENE, and the other trending NW-SE. No clear evidence has yet been found to demonstrate the relative ages of the two families of lineations, which are both associated with early thrusting (they may be penecontemporaneous). The scatter of $K_{1}$ at sites 912,9112 and 9122 might be due to the incomplete overprinting of one family of lineations by shearing along an oblique trajectory during $D_{1}$ thrusting.

An alternative interpretation would be that $D_{2}$ transcurrent shearing would cause subtle and localized microscale folding of $D_{1}$ fabrics, resulting in a $K_{1}$ parallel to the $F_{2}$ fold axis. Mesoscopic $F_{2}$ folding is widespread in the Opatica, though it has not been observed in the outcrops in question. Similar AMS fabrics have been demonstrated for black shales from subAlpine massifs in the French Alps (Rochette, 1988b; Aubourg et al., 1991). These authors demonstrate that an earlier $K_{1}$ preferred orientation, parallel to the transport trajectory of Alpine nappes, is locally overprinted by a $K_{1}$ orientation corresponding to a fold axis-parallel intersection lineation. Note that site 912 (Fig. $15 \mathrm{~g}$ ) is located only a few kilometers south of a major $D_{2}$ transcurrent ductile fault zone within which site 914 (Fig. 15e) is located (Fig. 2).

\section{Conclusions}

In all granitoids and gneisses of the Opatica belt, magnetic susceptibilities are highly variable, due mainly to varying contents of very pure, multi-domain magnetite. The magnetic mineralogy and susceptibilities of the Opatica rocks are similar to those for felsic plutons and crystalline gneisses form at least two similar terranes elsewhere in Superior Province (Williams et al., 1986; Shive and Fountain, 1988). The intensity of AMS of all the rocks appears to be strongly controlled by mineralogy rather than by strain or deformation state. Suite 1 gneisses have oblate susceptibility ellipsoids, in contrast with their $\mathrm{L}>\mathrm{S}$ classification based on mesoscopic structure.

The AMS technique was tested here primarily as a tool of structural geology. Our results show that AMS provides a viable method of indirectly determining petrofabrics in Archean granite-gneiss terranes where precise field measurements may otherwise be difficult to obtain due to outcrop conditions. Detailed comparison of field and laboratory measurements of mineral preferred orientations and AMS fabrics reveals that most often the average $K_{1}$ and $K_{3}$ principal susceptibility directions provide good estimations of the mineral and stretching lineations and poles to foliations. Where disagreement arises between orientations of $K_{1}$ and the observed lineations in the rocks, this may be attributed: (1) to complicated oxide mineralogy and textures which are a petrological feature of some plutonic rock types, or (2) in high grade gneisses, to subtle composite rock fabrics due to incomplete overprinting of mineral preferred orientation fabrics by subsequent deformation.

\section{Acknowledgements}

Much of the research presented here was carried out while K.B. held an NSERC-NATO Postdoctoral Fellowship, tenured at l'Université Paul-Sabatier, Toulouse. The work was supported by grants from LITHOPROBE and Energy, Mines and Resources Canada to E.W. Sawyer, from URA CNRS no. 67 to J.-L. Bouchez, and by an NSERC operating grant to K. Benn. J.K. Park provided helpful comments on an early version of the manuscript. The authors are grateful for reviews by G.J. 
Borradaile and B.R. Lienert. E. Hearn is acknowledged for drafting some of the figures. This paper is LITHOPROBE Publication No. 385.

\section{References}

Aubourg, Ch., Rochette, P. and Vialon, P., 1991. Subtle stretching lineation revealed by magnetic fabric of Callovian-Oxfordian black shales (French Alps). Tectonophysics, 185: 211-223.

Bailey, M.E. and Dunlop, D.J., 1983. Alternating field characteristics of pseudo-single-domain (2-14 $\mu \mathrm{m})$ and multidomain magnetite. Earth Planet. Sci. Lett., 63: 335-352.

Benn, K., Sawyer, E.W. and Bouchez, J.-L., 1992. Orogen-parallel and transverse shearing in the Opatica belt, Quebec: implications for the structure of the Abitibi Subprovince. Can. J. Earth Sci., 29: 2429-2444.

Berthé, D., Choukroune, P. and Jegouzo, P., 1979. Orthogneiss, mylonite and non coaxial deformation of granites: the example of the South Armorican Shear Zone. J. Struct. Geol., 1: 31-42.

Borradaile, G.J., 1988. Magnetic susceptibility, petrofabrics and strain. Tectonophysics, 156: 1-20.

Borradaile, G. and Spark, R., 1991. Deformation of the Archean Quetico-Shebandowan Subprovince boundary in the Canadian Shield near Kashabowie, northern Ontario. Can. J. Earth Sci., 28: 116-125.

Borradaile, G.J., Keeler, W., Alford, C. and Sarvas, P., 1987. Anisotropy of magnetic susceptibility of some metamorphic minerals. Phys. Earth Planet. Inter., 48: 161-166.

Borradaile, G.J., Sarvas, P., Dutka, R., Stewart, R. and Stubley, M., 1988. Transpression in slates along the margin of an Archean gneiss belt, northern Ontariomagnetic fabrics and petrofabrics. Can. J. Earth Sci., 25: 1069-1077.

Borradaile, G.J., MacKenzie, A. and Jensen, E., 1990. Silicate versus trace mineral susceptibility in metamorphic rocks. J. Geophys. Res., 95: 8447-8451.

Bouchez, J.-L., Bernier, S., Rochette, P. and Guineberteau, B., 1987. Log des susceptibilités magnétiques et anisotropies de susceptibilité dans le granite de Beauvoir: conséquences pour sa mise en place. In: BRGM (Editors), Géologie de la France, 2-3: 223-232.

Bouchez, J.-L., Gleizes, G., Djouadi, T. and Rochette, P., 1990. Microstructure and magnetic susceptibility applied to emplacement kinematics of granites: the example of the Foix pluton (French Pyrenees). Tectonophysics, 184: 157-171.

Card, K.D., 1990. A review of the Superior Province of the Canadian Shield, a product of Archean accretion. Precambrian Res., 48: 99-156.

Card, K.D. and Ciesielski, A., 1986. Subdivisions of the
Superior province of the Canadian Shield. Geosci. Can., 13: 5-13.

Dimroth, E., Imreh, L., Goulet, N. and Rocheleau, M., 1983. Evolution of the south-central segment of the Archean Abitibi Belt, Quebec, Part III. Plutonic and metamorphic evolution and geotectonic model. Can. J. Earth Sci., 20: 1374-1388.

Dunlop, D.J., 1983. Determination of domain structure in igneous rocks by alternating field and other methods. Earth Planet. Sci. Lett., 63: 353-367.

Dunlop, D.J., Schutts, L.D. and Hale, C.J., 1984. Paleomagnetism of Archean rocks from northwestern Ontario, III. Rock magnetism of the Shelley Lake granite, Quetico Subprovince. Can. J. Earth Sci., 21: 879-886.

Ellwood, B.B., Hrouda, F., Wagner, J.-J., 1988. Symposia on magnetic fabrics: introductory comments. Phys. Earth Planet. Inter., 51: 249-252.

Ernst, R.E. and Pearce, G.W., 1989. Averaging of anisotropy of magnetic susceptibility data, In: F.P. Agterberg and G.F. Bonham-Carter (Editors), Statistical Applications in the Earth Sciences. Geol. Surv. Can. Pap., 89-9: 297-305.

Gariépy, C. and Allègre, C.J., 1985. The lead isotope geochemistry and geochronology of late-kinematic intrusives from the Abitibi greenstone belt, and the implications for late Archean crustal evolution. Geochim. Cosmochim. Acta, 49: 2371-2383.

Goodwin, A.M., 1977. Archean basin-craton complexes and the growth of Precambrian shields. Can. J. Earth Sci., 14: 2737-2759.

Guillet, P., Bouchez, J.-L. and Wagner, J.-J., 1983. Anisotropy of magnetic susceptibility and magmatic structures in the Guérande granite massif (France). Tectonics, 2: 419-429.

Hanmer, S., 1987. Textural map units in quartzo-feldspathic mylonitic rocks. Can. J. Earth Sci., 24: 20652073.

Hocq, M., 1990. Map No. 2092 A-DV 89-04, Carte lithotectonique des sous-provinces de l'Abitibi et du Pontiac. Ministère de l'Energie et des Ressources du Québec, Quebec City.

Hrouda, F., 1982. Magnetic anisotropy of rocks and its application in geology and geophysics. Geophys. Surv., 5: 37-82.

Hrouda, F. and Kahan, S., 1991. The magnetic fabric relationship between sedimentary and basement nappes in the High Tatra Mountains, N. Slovakia. J. Struct. Geol., 13: 431-442.

Hudleston, P.J., Schultz-Ela, D. and Southwick, D.L., 1988. Transpression in an Archean greenstone belt, northern Minnesota. Can. J. Earth Sci., 25: 1060-1068.

Jackson, S.L., Sutcliffe, R.H., Ludden, J.N., Hubert, C., Green, A.G., Milkereit, B., Mayrand, L., West, G.F. and Verpaelst, P., 1990. Southern Abitibi greenstone belt: Archean crustal structure from seismic-reflection profiles. Geology, 18: 1086-1090.

Jelínek, V., 1978. Statistical processing of anisotropy of magnetic susceptibility measured on groups of speci- 
mens. Stud. Geoph. Geodyn., 22: 50-62.

Johnson, H.P., Lowrie, W. and Kent, D.V., 1975. Stability of anhysteretic remanent magnetization in fine and coarse magnetite and maghemite particles. Geophys. J. R. Astron. Soc., 41: 1-10.

Jover, O., Rochette, P., Lorand, J.P., Maeder, M. and Bouchez, J.-L., 1989. Magnetic mineralogy of some granites from the French Massif Central: origin of their low-field susceptibility. Phys. Earth Planet. Inter., 55: 79-92.

Khan, M.A., 1962. The anisotropy of magnetic susceptibility of some igneous and metamorphic rocks. J. Geophys. Res., 67: 2873-2885.

Launeau, P., Bouchez, J.-L. and Benn, K., 1990. Shape preferred orientations of object populations: automated analysis of digitized images. Tectonophysics, 180: 201-211.

Lienert, B.R., 1991. Monte Carlo simulation of errors in the anisotropy of magnetic susceptibility: a second-rank symmetric tensor. J. Geophys. Res., 96: 19539-19544.

Lowrie, W., 1990. Identification of ferromagnetic minerals in a rock by coercivity and unblocking temperature properties. Geophys. Res. Lett., 17: 159-162.

Lowrie, W. and Fuller, M., 1971. On the alternating field demagnetization characteristics of multidomain thermoremanent magnetization in magnetite. J. Geophys. Res., 76: 6339-6349.

MacDonald, W.D. and Ellwood, B.B., 1990. Magnetic vs. structural fabrics, Whipple detachment structure, Whipple Wash, California. Phys. Earth Planet. Inter., 64: 355-366.

Nagata, T., 1961. Rock Magnetism. Maruzen Co. Ltd., Tokyo, $350 \mathrm{pp}$.

Pearce, G.W. and Fueten, F., 1989. An intensive study of magnetic susceptibility anisotropy of amphibolite layers of the Thompson Belt, North Manitoba. Tectonophysics, 162: 315-329.

Percival, J.A. and Card, K.D., 1983. Archean crust as revealed in the Kapuskasing uplift, Superior province, Canada. Geology, 11: 323-326.

Percival, J.A. and McGrath, P.H., 1986. Deep crustal structure and tectonic history of the northern Kapuskasing uplift of Ontario: an integrated petrologicalgeophysical study. Tectonics, 5: 553-572.

Potter, D.K. and Stephenson, A., 1988. Single- domain particles in rocks and magnetic fabric analysis. Geophys. Res. Lett., 15: 1097-1 100.

Poulsen, K.H., Borradaile, G. and Kehlenbeck, M.M.,
1980. An inverted Archean succession at Rainy Lake, Ontario. Can. J. Earth Sci., 10: 1358-1369.

Racicot, D., Chown, E.H. and Hanel, T., 1984. Plutons of the Chibougamau-Desmaraisville belt: a preliminary survey. Can. Inst. Min., Spec. Vol., 34: 178-197.

Ramsdohr, P., 1980. The Ore Minerals and their Intergrowths, Vol. 2. Pergamon Press, New York, 1207 pp.

Rathore, J.S., 1985. Some magnetic fabric characteristics of sheared zones. Geodynamics, 2: 291-301.

Rochette, P., 1987. Magnetic susceptibility of the rock matrix related to magnetic fabric studies. J. Struct. Geol., 9: 1015-1020.

Rochette, P., 1988a. Inverse magnetic fabric in carbonate-bearing rocks. Earth Planet. Sci. Lett., 90: 229-237.

Rochette, P., 1988b. Relations entre déformation et métamorphisme alpin dans les schistes noirs helvétiques: l'apport de la fabrique magnétique. Geodin. Acta, 2: 17-24.

Rochette, P., Jackson, M. and Aubourg, C., 1992. Rock magnetism and the interpretation of anisotropy of magnetic susceptibility. Rev. Geophys., in press.

Ruf, A.S., Naruk, S.J., Butler, R.F. and Calderone, G.J., 1988. Strain and magnetic fabric in the Santa Catalina and Pinaleno Mountains metamorphic core complex mylonite zones, Arizona. Tectonics, 7: 235-248.

Sawyer, E.W. and Benn, K., 1993. Structure of the highgrade Opatica belt and adjacent low-grade Abitibi Subprovince: an Archean mountain front. J. Struct. Geol., in press.

Shive, P.N. and Fountain, D.M., 1988. Magnetic mineralogy in an Archean crustal cross section: implications for crustal magnetization. J. Geophys. Res., 93: 1217712186.

Uyeda, E., Fuller, M.D., Belshé, J.C. and Girdler, R.W., 1963. Anisotropy of magnetic susceptibility of rocks and minerals. J. Geophys. Res., 68: 279-291.

Wagner, J.J., Hedley, I.G., Steen, D., Tinkler, C. and Vuagnat, M., 1981. Magnetic anisotropy and fabric of some progressively deformed ophiolitic gabbros. J. Geophys. Res., 86: 307-315.

Williams, H.R., 1990. Subprovince accretion tectonics in the south-central Superior Province. Can. J. Earth Sci., 27: 570-581.

Williams, M.C., Shive, P.N., Fountain, D.M. and Frost, B.R., 1986. Magnetic properties of exposed deep crustal rocks from the Superior Province of Manitoba. Earth Planet. Sci. Lett., 76: 176-184. 